\title{
A Novel Allosteric Potentiator of AMPA Receptors: 4-[2-(Phenylsulfonylamino)ethylthio]-2,6-Difluoro-Phenoxyacetamide
}

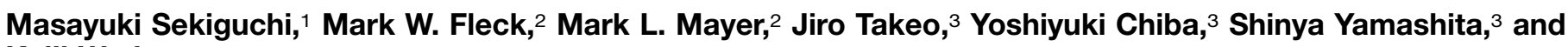 \\ Keiji Wada ${ }^{1}$ \\ ${ }^{1}$ Department of Degenerative Neurological Diseases, National Institute of Neuroscience, National Center of Neurology and \\ Psychiatry, Kodaira, Tokyo 187, Japan, ${ }^{2}$ Laboratory of Cellular and Molecular Neurophysiology, National Institute of Child \\ Health and Human Development, National Institutes of Health, Bethesda, Maryland 20892-4495, and ${ }^{3}$ Central Research \\ Laboratory, Nippon Suisan Kaisha Limited, Hachioji, Tokyo 192, Japan
}

\begin{abstract}
We report that a novel sulfonylamino compound, 4-[2-(phenylsulfonylamino)ethylthio]-2,6-difluoro-phenoxyacetamide (PEPA), selectively potentiates glutamate receptors of the AMPA subtype. PEPA $(1-200 \mu \mathrm{M})$ dose dependently potentiated glutamateevoked currents in Xenopus oocytes expressing AMPA (GluRAGluRD), but not kainate (GluR6 and GluR6+KA2) or NMDA ( $\zeta 1+$ $\epsilon 1-\epsilon 4)$, receptor subunits. PEPA was effective at micromolar concentrations and, in contrast to the action of cyclothiazide, preferentially modulated AMPA receptor flop isoforms. At $200 \mu \mathrm{M}$, PEPA potentiated glutamate responses by 50 -fold in oocytes expressing GluRC $_{\text {flop }}\left(\mathrm{EC}_{50} \sim 50 \mu \mathrm{M}\right)$ versus only threefold for $\mathrm{GluRC}_{\text {flip }}$; a similar preference for flop isoforms was observed for other AMPA receptor subunits. Dose-response analysis for $\mathrm{GluRC}_{\text {flop }}$ revealed that $100 \mu \mathrm{M}$ PEPA produced a sevenfold increase in AMPA recep-
\end{abstract}

Allosteric modulation of the three subtypes of ionotropic glutamate receptors-AMPA, kainate, and NMDA receptors-is produced by a diverse spectrum of agents, including lectins, a variety of drugs, polyamines, and divalent cations. The unusually strong modulation of AMPA receptors by the benzothiadiazine and pyrrolidinone compounds cyclothiazide, aniracetam, and their derivatives (Ito et al., 1990; Isaacson and Nicoll, 1991; Tang et al., 1991; Vyklicky et al., 1991; Hestrin, 1992; Yamada and Rothman, 1992; Bertolino et al., 1993; Patneau et al., 1993; Yamada and Tang, 1993; Arai et al., 1994; Staubli et al., 1994a,b) is especially interesting, because these drugs potentiate excitatory synaptic transmission and have the potential for therapeutic use as nootropic agents.

AMPA receptors are hetero-oligomeric complexes, most likely pentamers (Wenthold et al., 1992; Ferrer-Montiel and Montal, 1996), generated by the assembly of various combinations of four subunits named GluRA, GluRB, GluRC, and GluRD or GluR1, GluR2, GluR3, and GluR4, respectively (Hollmann et al., 1989;

\footnotetext{
Received March 14, 1997; revised May 19, 1997; accepted May 20, 1997.

This investigation was supported in part by research grants from the Ministry of Education, Science, Sports, and Culture, the Ministry of Health and Welfare, the Science and Technology Agency of Japan, and the Japan Foundation for Neuroscience and Mental Health. We thank Drs. S. Heinemann, M. Mishina, and P. Seeburg for cDNAs; Drs. M. Hollmann and R. Wenthold for their critical comments; and Drs. T. Nishikawa and K. Takahashi for comments and amino acid analysis via HPLC.

Correspondence should be addressed to Dr. Masayuki Sekiguchi, Department of Degenerative Neurological Diseases, National Institute of Neuroscience, National Center of Neurology and Psychiatry, 4-1-1 Ogawahigashi, Kodaira, Tokyo 187, Japan.

Copyright (C) 1997 Society for Neuroscience $\quad 0270-6474 / 97 / 175760-12 \$ 05.00 / 0$
}

tor affinity for glutamate. PEPA produced considerably weaker potentiation of kainate-evoked than glutamate-evoked currents, suggesting modulation of the process of receptor desensitization. In human embryonic kidney 293 cells transfected with AMPA receptor subunits, PEPA either abolished or markedly slowed the rate of onset of desensitization and potentiated steady-state equilibrium currents evoked by glutamate with subunit (GluRC $\geq$ GluRD > GluRA) and splice-variant (flop > flip) selectivity similar to that observed in oocytes. Our results show that PEPA is a novel, flop-preferring allosteric modulator of AMPA receptor desensitization at least 100 times more potent than aniracetam.

Key words: glutamate receptors; AMPA; desensitization; alternative splicing; flip and flop; allosteric modulation
Boulter et al., 1990; Keinänen et al., 1990). Each subunit exists in flip and flop isoforms generated by alternative splicing (Sommer et al., 1990), and their expression is regulated both regionally and developmentally (Boulter et al., 1990; Keinänen et al., 1990; Sommer et al., 1990; Monyer et al., 1991). Because the assembly of AMPA receptors containing more than one type of subunit appears not to require a fixed stoichiometry, it is possible to generate a diverse array of receptor subtypes that differ in important functional properties. For example, subunit composition can affect the affinity for various agonists and antagonists (Stein et al., 1992). Splice-variant composition affects the kinetics of receptor deactivation, the rate of onset and recovery from desensitization, and modulation by cyclothiazide and aniracetam (Lomeli et al., 1994; Mosbacher et al., 1994; Partin et al., 1994). Assembly of GluRB with other subunits reduces $\mathrm{Ca}^{2+}$ permeability (Hollmann et al., 1991; Hume et al., 1991; Sommer et al., 1991), single-channel conductance (Swanson et al., 1997), and rectification resulting from channel block by polyamines (Verdoorn et al., 1991; Bowie and Mayer, 1995).

Although the physiological significance of the cell-specific expression of AMPA receptor subunits and splice variants is not yet fully understood, it is likely that the regulation of receptor composition determines the kinetics and strength of transmission at glutamatergic synapses. As such, drugs that modulate AMPA receptors are both useful pharmacological tools as well as potential therapeutic agents. The modulation of AMPA receptors by aniracetam and cyclothiazide, the most thoroughly examined agents, reveals profound differences in potency, pharmacological selectivity, and mechanism of action. Aniracetam is effective at 
millimolar concentrations and preferentially modulates flop splice variants (Johansen et al., 1995; Partin et al., 1996), whereas cyclothiazide is effective at micromolar concentrations and preferentially modulates flip splice variants (Partin et al., 1994, 1996).

Here we report that a novel sulfonylamino compound, PEPA, which is structurally distinct from the previously characterized pyrrolidinone or benzothiadiazine compounds typified by aniracetam and cyclothiazide (see Fig. 1), potentiates currents of recombinant AMPA receptors expressed in Xenopus oocytes. PEPA is effective at micromolar concentrations, is selective for the AMPA subtype of glutamate receptors, and preferentially modulates flop splice variants. Rapid perfusion experiments in transfected human embryonic kidney 293 (HEK 293) cells show that potentiation by PEPA results primarily from attenuation of desensitization.

\section{MATERIALS AND METHODS}

Xenopus oocyte expression system. Glutamate receptor expression in Xenopus oocytes was performed as described previously (Sekiguchi et al., 1994). Briefly, cRNA was prepared from linearized cDNA encoding glutamate receptors by in vitro transcription. The cDNAs encoding rat GluR $1_{\text {flop }}$, GluR2 $2_{\text {flop }}$, GluR $3_{\text {flop }}$, GluR6, and KA2 were kindly provided by Dr. Steven Heinemann (The Salk Institute for Biological Studies, San Diego, CA). In Results, these are referred to as GluRA, GluRB, and GluRC to maintain consistent nomenclature with experiments on HEK 293 cells, which were performed with cDNAs from Dr. Peter Seeburg. The flip variants of GluR1, GluR2, and GluR3 were prepared from corresponding flop cDNAs by using site-directed mutagenesis (MutaGene Phagemid kit, Bio-Rad, Hercules, CA) as described previously (Sekiguchi et al., 1994; Matsui et al., 1995). The mutations were confirmed by sequence analysis. Oocyte expression plasmids encoding GluRD flop $_{\text {fl }}$ and GluRD flip were provided by Dr. Seeburg (University of Heidelberg, Heidelberg, Germany). The R/G sites in GluR $2_{\text {flip }}$ and GluR $3_{\text {flip }}$ (both $\mathrm{G}$ versions) are the same as in their original flop clones; the sites in GluRD were R (flip) and G (flop). The cDNAs encoding mouse NMDA receptors were kindly provided by Dr. M. Mishina (University of Tokyo, Tokyo, Japan).

The concentration of the cRNA solution injected into oocytes was 1 $\mathrm{mg} / \mathrm{ml}$, and $50 \mathrm{nl}$ of the solution was injected into an oocyte. The ratio of GluRA, GluRC, or GluRD to GluRB was 1:1, unless specified otherwise. Electrophysiological responses were recorded 4-6 d after injection with a two-electrode voltage clamp at a holding potential of $-100 \mathrm{mV}$, unless otherwise specified. Oocytes were perfused with frog Ringer's solution consisting of (in $\mathrm{mM}$ ): $115 \mathrm{NaCl}, 2 \mathrm{KCl}, 1.8 \mathrm{CaCl}_{2}$, and $10 \mathrm{HEPES}, \mathrm{pH}$ 7.2 with $\mathrm{NaOH}$. PEPA was dissolved in dimethylsulfoxide (DMSO), usually at $100 \mathrm{~mm}$, and added to frog Ringer's solution to yield final concentrations of $0.2-200 \mu \mathrm{M}$; the final concentration of DMSO was no more than $0.2 \%$. The $\mathrm{pH}$ of the frog Ringer's solution was not changed by adding $200 \mu \mathrm{M}$ PEPA. At room temperature no precipitation was observed in the PEPA-DMSO-frog Ringer's solution up to $200 \mu \mathrm{M}$ PEPA. Concanavalin A (Sigma, St. Louis, MO) was dissolved in frog Ringer's solution $(1 \mathrm{mg} / \mathrm{ml})$, and the oocytes were incubated in this solution for $\sim 3 \mathrm{~min}$ at room temperature before recording.

Rapid perfusion experiments in HEK 293 cells. Plasmids encoding cDNA clones of rat GluRA, GluRB, GluRC, and GluRD flip $\left({ }_{i}\right)$ and flop $\left(_{o}\right)$ in CMV expression vectors (gifts from Dr. Peter Seeburg) were prepared by alkaline lysis, followed by $2 \times$ cesium chloride gradient purification. HEK 293 cells (ATCC CRL 1573) were plated at low density on $35 \mathrm{~mm}$ Petri dishes and transfected $24 \mathrm{hr}$ later, using the calcium phosphate precipitation technique of Chen and Okayama (1987). Cells were maintained in MEM with Earle's salts, $2 \mathrm{~mm}$ glutamine, and $10 \%$ fetal bovine serum. Heteromeric receptors were examined by cotransfection of GluRA, GluRC, or GluRD with GluRB (at a ratio of 1:2); heteromerization was confirmed by analysis of current-voltage plots as described previously (Partin et al., 1994), and data were excluded for cells with significant inward rectification. Whole-cell recordings from isolated HEK 293 cells were obtained $40-72 \mathrm{hr}$ after transfection, using an Axopatch-200B amplifier (Axon Instruments, Foster City, CA), at a holding potential of $-60 \mathrm{mV}$. Extracellular recording solution contained (in mM): $145 \mathrm{NaCl}, 5.4 \mathrm{KCl}, 1.8 \mathrm{CaCl}_{2}, 1 \mathrm{MgCl}_{2}, 5 \mathrm{HEPES}$, and 0.01

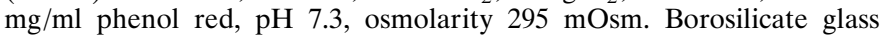
pipettes (WPI 1B150F, World Precision Instruments, Sarasota, FL) had

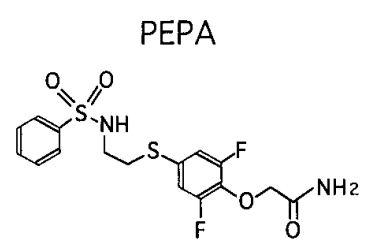

\section{Cyclothiazide}

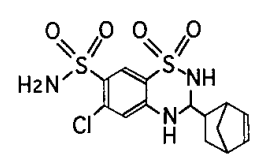

Aniracetam

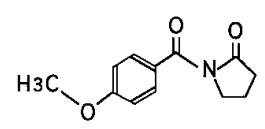

Figure 1. Chemical structures of PEPA, cyclothiazide, and aniracetam.

resistances of 2-5 M $\Omega$ when filled with (in $\mathrm{mM}$ ): $135 \mathrm{CsCl}, 10 \mathrm{CsF}, 0.5$ $\mathrm{CaCl}_{2}, 1 \mathrm{MgCl}_{2}, 10 \mathrm{HEPES}$, and $5 \mathrm{Cs}_{4}$-BAPTA, $\mathrm{pH} 7.2$, osmolarity 295 $\mathrm{mOsm}$. Solutions were applied at a flow rate of $0.67 \mathrm{ml} / \mathrm{min}$ controlled by a syringe pump (WPI sp220i) with a stepper motor-based fast perfusion system as described previously (Vyklicky et al., 1991). Responses were filtered at $2-5 \mathrm{kHz}$ (8-pole Bessel filter), digitized as required, and stored on a MacIntosh PPC 7600/132 computer by using a 16-bit AD converter (Instrutech ITC-16, Great Neck, NY) under control of the data acquisition and analysis program Synapse (Synergy Research, Silver Spring, $\mathrm{MD})$. The control barrel of the fast perfusion system contained normal extracellular solution; the other barrels contained $3 \mathrm{mM}$ L-glutamate, 100 $\mu \mathrm{M}$ PEPA, or both. PEPA was dissolved in DMSO at $100 \mathrm{~mm}$ before dilution in extracellular solution, and an equivalent final concentration of DMSO $(0.1 \%)$ was added to all glutamate and control solutions not containing PEPA. The time constant of onset of desensitization $\left(\tau_{\mathrm{des}}\right)$ in the presence and absence of PEPA was fit by a single exponential function for all subunits except GluRA $A_{i}$, for which responses in the presence of PEPA were better fit by the sum of two exponentials (see Fig. $9 A)$. The onset $\left(\tau_{\text {on }}\right)$ and recovery $\left(\tau_{\text {off }}\right)$ from potentiation in response to rapid application of PEPA (see Fig. $8 B$, Table 1) were fit with one $\left(\tau_{\text {on }}\right)$ or the sum of two $\left(\tau_{\text {off }}\right)$ exponentials for all subunits.

\section{RESULTS}

The action of PEPA (Fig. 1) on glutamate receptors was discovered via electrophysiological screening of compounds containing sulfonylamino groups, using the Xenopus oocyte expression system and poly $\left(\mathrm{A}^{+}\right)$mRNA prepared from rat brain. PEPA was synthesized originally in the process of developing thromboxane A2 receptor antagonists (Sato et al., 1994, 1995), but the activity of PEPA on A2 receptors has not yet been tested. PEPA produced small inward current responses in oocytes expressing AMPA receptor flop splice variants but did not evoke current responses in control oocytes prepared from four different frogs and injected with water $(n=45)$. PEPA $(200 \mu \mathrm{M})$ injected into oocytes $(20$ nl/oocyte) also did not elicit current responses $(n=3)$. When the PEPA sample or frog Ringer's solution used in these experiments was analyzed by HPLC (the analysis system could detect concentrations exceeding $10 \mathrm{~nm}$ ), no contaminating glutamate or aspartate peaks were detected. When it was applied by concentration jump to HEK 293 cells transfected with glutamate receptor subunits, PEPA $(100 \mu \mathrm{M})$ failed to activate rapidly desensitizing responses even in cells expressing AMPA receptors at high density. Because subsequent experiments revealed a profound potentiation of glutamate responses by PEPA, we focused our attention on the modulatory action of PEPA and have not yet determined 
A
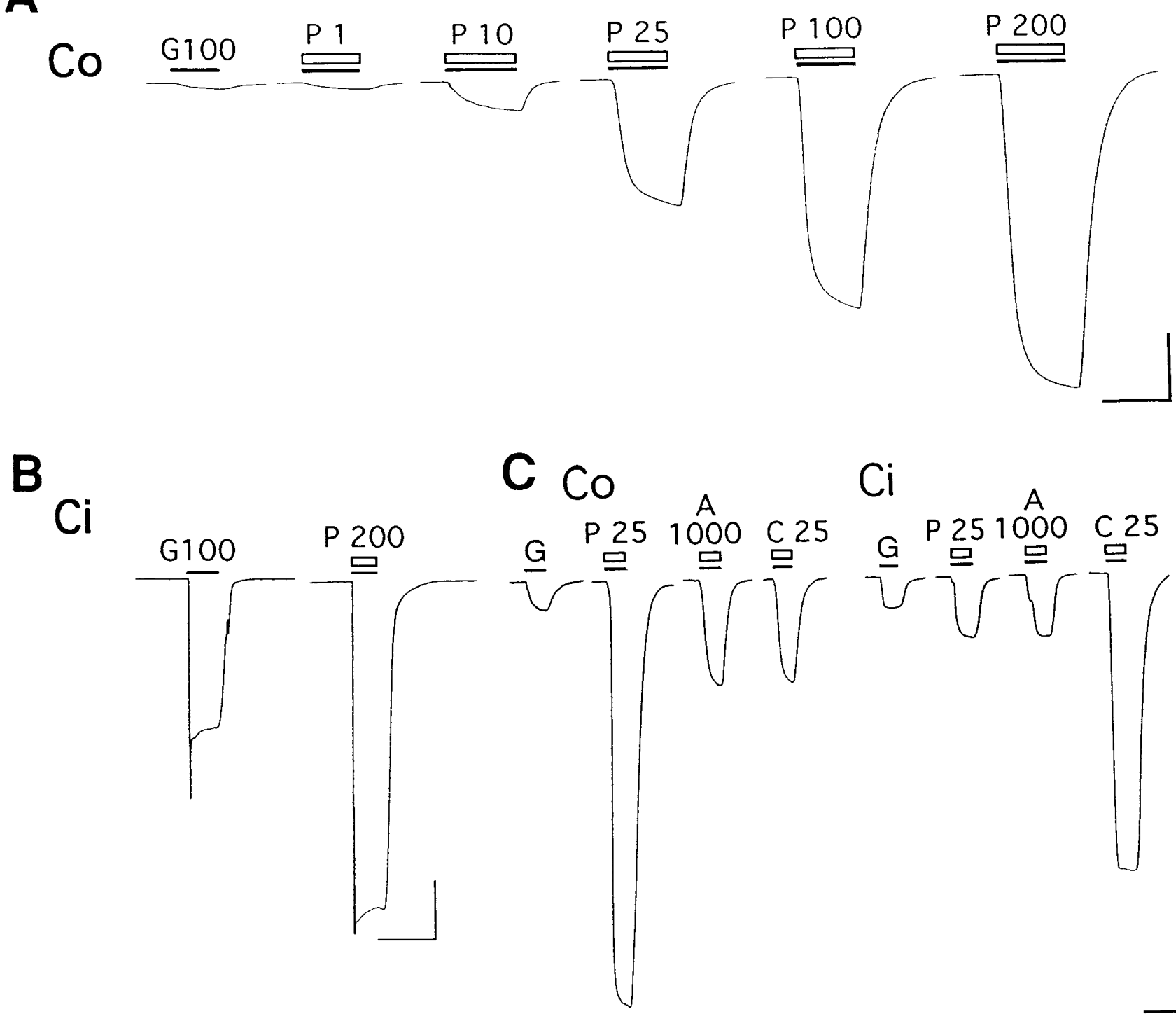

$\mathrm{Ci}$
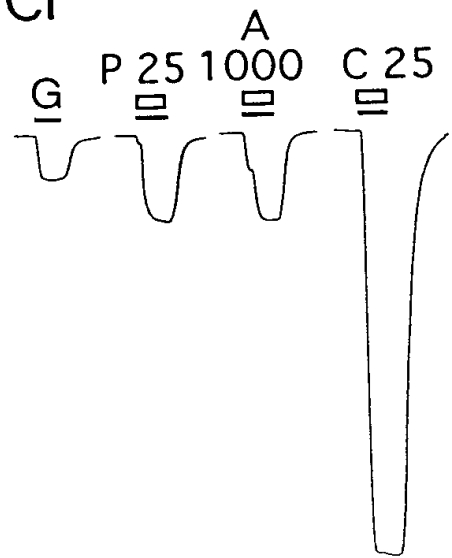

Figure 2. PEPA strongly potentiates glutamate-evoked currents in oocytes expressing $\mathrm{GluRC}_{\mathrm{o}} . A, B$, Potentiation by PEPA of glutamate-evoked currents in Xenopus oocytes expressing GluRC $\mathrm{o}_{\mathrm{o}}$ and/or $\mathrm{GluRC}_{\mathrm{i}}$. Glutamate, $100 \mu \mathrm{M}$, was applied during the periods indicated by filled bars $(G 100)$. PEPA was applied at the indicated concentrations (in $\mu \mathrm{M})$ during the periods indicated by open bars $(P 1-P$ 200). Holding potential, $-70 \mathrm{mV}$; calibration, 20 sec and $100 \mathrm{nA}$. $C$, The potentiation of $100 \mu \mathrm{M}$ glutamate-evoked currents by PEPA $[P 25(\mu \mathrm{M})]$, aniracetam $[A 1000(\mu \mathrm{M})]$, and cyclothiazide $[C 25(\mu \mathrm{M})]$

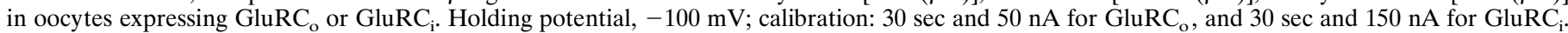

the mechanism or mechanisms underlying the small amplitude responses to PEPA itself recorded with Xenopus oocytes.

\section{PEPA potentiates AMPA receptor responses with opposite splice-variant selectivity to cyclothiazide}

Figure $2 A$ shows the effects of various concentrations of PEPA on currents evoked by $100 \mu \mathrm{M}$ glutamate in an oocyte expressing GluRC $_{\mathrm{o}}$. Glutamate-evoked currents were strongly potentiated by PEPA in a concentration-dependent manner. In contrast, Figure $2 B$ shows the much weaker potentiation by $200 \mu \mathrm{M}$ PEPA of glutamate-evoked currents in an oocyte expressing GluRC $_{\mathrm{i}}$. The amount of potentiation by PEPA $(200 \mu \mathrm{M})$ was consistently much greater for GluRC $\mathrm{o}_{\mathrm{o}}(50.2 \pm 10.7$-fold, $n=7)$ than for GluRC ( $2.7 \pm 0.3$-fold, $n=10)$. Figure $2 C$ compares the splice-variant selective action of $25 \mu \mathrm{M}$ PEPA with the action of $1 \mathrm{~mm}$ aniracetam and $25 \mu \mathrm{M}$ cyclothiazide, two well characterized allosteric modulators of AMPA receptors. PEPA caused much greater potentiation of glutamate responses in oocytes expressing GluRC $_{\mathrm{o}}$ than either aniracetam or cyclothiazide. In contrast, cyclothiazide caused the greatest potentiation in oocytes express-

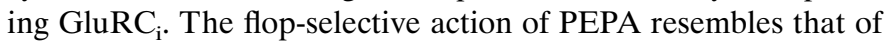
aniracetam, but clearly PEPA is considerably more potent; in fact, potentiation by $25 \mu \mathrm{M}$ PEPA for $\mathrm{GluRC}_{\mathrm{o}}$ responses $(21.5 \pm$ 3.9-fold, $n=7$ ) was even larger than that produced by $25 \mu \mathrm{M}$ cyclothiazide for GluRC $\mathrm{i}_{\mathrm{i}}$ responses $(13.4 \pm 2.4$-fold, $n=6)$.

In an attempt to define accurately the differences in the potency for modulation of AMPA receptors by PEPA and aniracetam, we performed dose-response analyses in oocytes expressing GluRC $_{\mathrm{o}}$ or $\mathrm{GluRC}_{\mathrm{i}}$. Figure 3 shows potentiation by PEPA and aniracetam expressed as the fold increase in responses to $100 \mu \mathrm{M}$ glutamate when coapplied with modulator. Both aniracetam and PEPA were flop-preferring and produced much greater potentiation for GluRC $C_{0}$ than for GluRC $_{i}$ at their limit of solubility in 


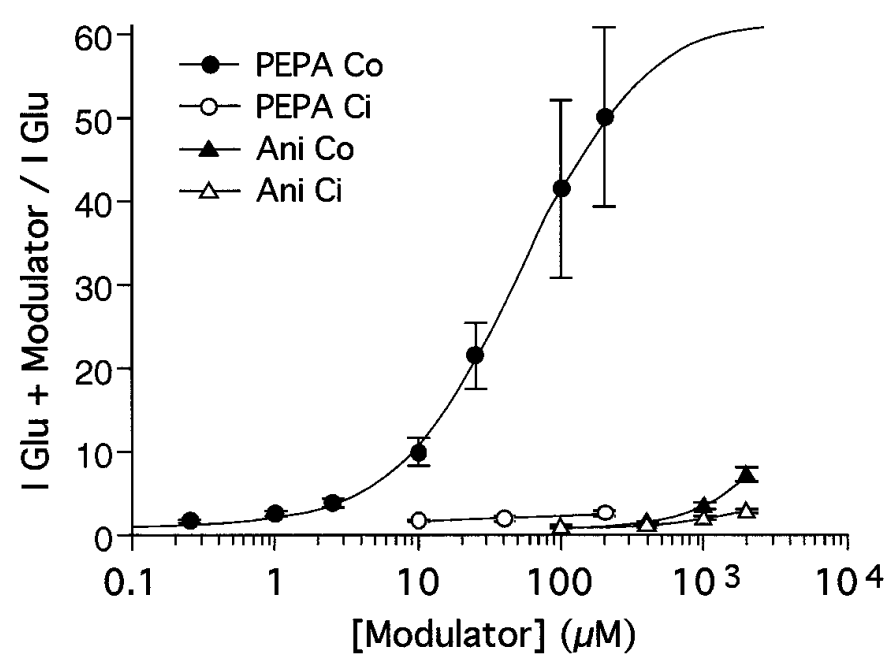

Figure 3. PEPA is much more potent than aniracetam. Shown are dose-response curves for potentiation of glutamate responses by PEPA and aniracetam $(\mathrm{Ani})$ in oocytes expressing $\mathrm{GluRC}_{\mathrm{o}}$ and $\mathrm{GluRC}_{\mathrm{i}}$. Glutamate $(100 \mu \mathrm{M})$ was applied first to oocytes to obtain control responses, and then solutions containing both glutamate and various concentrations of PEPA or aniracetam were applied. Ordinate, Fold potentiation is given as the amplitude of the response evoked by coapplication of glutamate plus modulator/amplitude of the response to glutamate alone. In the case of GluRC $\mathrm{o}_{\mathrm{o}}$, the dose-response curve for PEPA indicates the best fit to the data according to the logistic function $P=1+P_{\max } /\left[1+\left(\mathrm{EC}_{50} /[D]\right)^{n}\right]$, in which $P$ is the fold potentiation, $P_{\max }$ is the maximal potentiation, $\mathrm{EC}_{50}$ is the concentration causing $50 \%$ of maximal potentiation, $[D]$ is the concentration of PEPA, and $n$ is the Hill coefficient. The other data were connected simply by lines. The apparent $\mathrm{EC}_{50}$ for potentiation of GluRC by PEPA was $50.4 \mu \mathrm{M}($ Hill coefficient $=1.03)$. Values are mean $\pm \mathrm{SEM}$ $(n=6-8)$. SEM is smaller than the symbol for data points in which the error bars are not visible.

frog Ringer's solution. The $\mathrm{EC}_{50}$ for potentiation of $\mathrm{GluRC}_{\mathrm{o}}$ by PEPA was $50 \mu \mathrm{M}$ (Hill coefficient $=1.03)$. Aniracetam did not produce any detectable potentiation at $100 \mu \mathrm{M}$, and at $1-2 \mathrm{~mm}$ it produced almost comparable potentiation to only $10 \mu \mathrm{M}$ PEPA. Although complete dose-response curves could not be constructed for aniracetam because of its limited solubility and low potency, our data indicate that PEPA was at least 100 times more potent for potentiation of GluRC $_{\mathrm{o}}$ than aniracetam (Fig. 3). Dose-response analysis of PEPA modulation for $\mathrm{GluRC}_{\mathrm{i}}$ suffered from similar limitations to those for analysis of the effects of aniracetam, and within the concentration range that it was possible to analyze we were unable to determine whether the maximum potentiation by PEPA for GluRC $\mathrm{C}_{\mathrm{i}}$ was less than for GluRC or whether, in addition, the $\mathrm{EC}_{50}$ of PEPA for $\mathrm{GluRC}_{\mathrm{i}}$ was greater than the $\mathrm{EC}_{50}$ for GluRC . $_{\text {. }}$

The flop-preferring action of aniracetam has been reported previously for studies comparing GluR $\mathrm{A}_{\mathrm{o}} \mathrm{B}_{\mathrm{o}}$ with GluR $\mathrm{A}_{\mathrm{i}} \mathrm{B}_{\mathrm{i}}$ and GluRB $\mathrm{o}_{\mathrm{o}} \mathrm{D}_{\mathrm{o}}$ with GluRB $\mathrm{D}_{\mathrm{i}}$ expressed in oocytes (Johansen et al., 1995) and for homomeric GluR $A_{o}$ compared with homomeric GluRA $_{i}$ expressed in HEK 293 cells (Partin et al., 1996). To determine whether the selectivity of PEPA for GluRC $_{o}$ versus GluRC $_{i}$ was maintained in other AMPA receptor subunits, we compared potentiation of responses to glutamate by $200 \mu \mathrm{M}$ PEPA for GluRA, GluRC, and GluRD expressed alone and in combination with GluRB. Figure 4 shows that PEPA caused consistently greater enhancement of currents evoked by $100 \mu \mathrm{M}$ glutamate in oocytes expressing AMPA receptor flop versus flip isoforms for all subunits examined. However, there were clear differences among subunits and between homomeric receptors

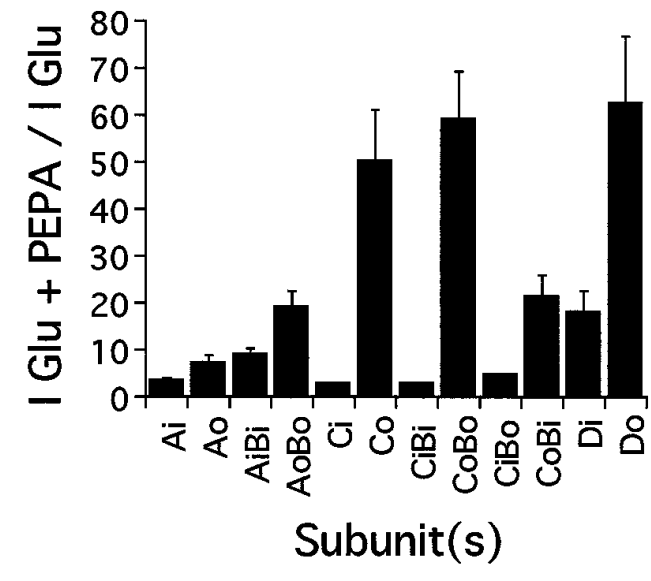

Figure 4. Subunit and splice-variant selectivity of the action of PEPA. Oocytes were injected with the AMPA receptor subunit cRNAs denoted. Glutamate $(100 \mu \mathrm{M})$ was applied first to oocytes, and then a solution containing both glutamate $(100 \mu \mathrm{M})$ and PEPA $(200 \mu \mathrm{M})$ was applied. Ordinate, Fold potentiation is given as the amplitude of the response evoked by coapplication of glutamate plus PEPA/amplitude of the response to glutamate alone. Values are mean $\pm \operatorname{SEM}(n=5-22)$.

versus heteromeric receptors generated by coassembly with GluRB. GluRA $A_{\text {o }}$ was the least sensitive of the flop variants, but nonetheless it showed greater potentiation than GluRA $A_{i}$ (Fig. 4). Coassembly with GluRB $_{\mathrm{o}}$ increased potentiation by PEPA for GluRA $A_{o}$. In heteromeric receptors formed from GluRB and GluRC, the magnitude of enhancement by PEPA was dependent on the splice isoform of GluRC; although marked potentiation was observed for $\mathrm{GluRB}_{\mathrm{o}} \mathrm{C}_{\mathrm{o}}$, only moderate potentiation was observed for GluRB $\mathrm{C}_{\mathrm{o}}$, whereas GluRB $\mathrm{C}_{i}$ and GluRB $\mathrm{C}_{\mathrm{i}}$ were potentiated only weakly. Because these subunits were injected at a ratio of $1: 1$, it is possible that the results obtained reflect formation of homomeric GluRC rather than a dominant effect of the GluRC subunit.

\section{PEPA is selective for AMPA subclass ionotropic glutamate receptors}

Next, we tested effects of PEPA on other glutamate receptor subtypes. Figure $5 A$ shows traces obtained from two oocytes expressing GluR6, a kainate receptor subunit. The oocyte shown in the top traces was untreated, and that in the bottom traces was treated with concanavalin A to block desensitization, as described in Materials and Methods. For the untreated oocyte, responses to $100 \mu \mathrm{M}$ glutamate were separated by $10 \mathrm{~min}$ intervals to allow recovery from desensitization; then PEPA $(100 \mu \mathrm{M})$ and glutamate were applied simultaneously, and the oocyte was washed with Ringer's solution again for $10 \mathrm{~min}$ to confirm recovery. After treatment with concanavalin A, solutions were applied by using the same order but with applications of glutamate separated by 1 min intervals. In contrast to its effects on AMPA receptors, PEPA did not potentiate the glutamate-evoked currents for GluR6 $(n=$ 10) either before or after reduction of desensitization by concanavalin A; instead, PEPA caused a modest but reproducible inhibition, which was not observed with the $0.1 \%$ DMSO present in $100 \mu \mathrm{M}$ PEPA solutions. Similar experiments performed in oocytes expressing the kainate receptor subunits GluR6 plus KA2 $(n=10)$ confirmed that there was also no potentiation by PEPA of these receptors (Fig. $5 B$ ). Currents evoked by simultaneous application of glutamate and glycine $(10 \mu \mathrm{M}$ each $)$ in oocytes expressing the NMDA receptor subunits $\zeta$ plus subunits 


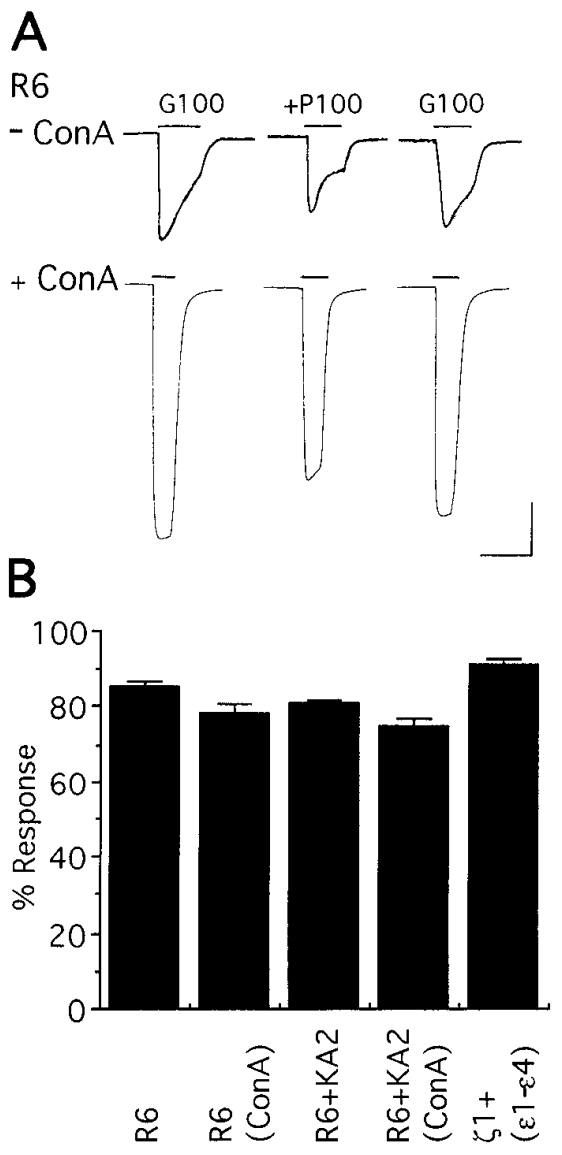

Figure 5. PEPA is selective for AMPA subtype glutamate receptors. $A$, Action of PEPA $(100 \mu \mathrm{M})$ on glutamate responses $(100 \mu \mathrm{M})$ of oocytes expressing GluR6, which were untreated $(-\operatorname{Con} A)$ or pretreated with Concanavalin A $(+\operatorname{Con} A)$ before recording. Left traces are control glutamate currents $(G 100)$; middle traces show responses to coapplication of glutamate + PEPA $(+P 100)$; right traces show recovery. Calibration: 20 sec for all traces, and $50 \mathrm{nA}$ for - ConA or $100 \mathrm{nA}$ for + ConA. B, Similar experiments were performed in oocytes expressing GluR6 + KA2 (1:1) or $\zeta 1+\epsilon 1+\epsilon 2+\epsilon 3+\epsilon 4$ (4:1:1:1:1). Ordinate, Percentage of response is given as the amplitude of the response evoked by glutamate $(100 \mu \mathrm{M}$ for kainate receptors and $10 \mu \mathrm{M}$ for NMDA receptors) plus PEPA (100 $\mu \mathrm{M})$ /amplitude of the response to glutamate alone. Values are mean \pm SEM $(n=5-15)$. In oocytes expressing NMDA receptor subunits, glycine $(10 \mu \mathrm{M})$ was coapplied with glutamate.

$\epsilon 1-\epsilon 4(n=11)$ also were not potentiated by PEPA (Fig. $5 B)$; a very small response was elicited by glutamate without glycine in these oocytes, which also was not potentiated by PEPA (data not shown).

\section{PEPA increases GluRC $C_{0}$ apparent affinity for glutamate}

Cyclothiazide has been shown previously to cause a leftward shift in the agonist dose-response relationship for native AMPA receptors in hippocampal neurons and for GluRA $A_{i}$ expressed in oocytes (Patneau et al., 1993; Yamada and Tang, 1993; Partin et al., 1994); in contrast, it has been reported that aniracetam produces a shift to the right of the glutamate dose-response

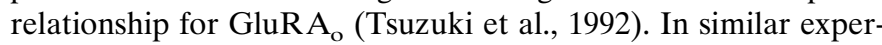
iments we observed that PEPA $(10-100 \mu \mathrm{M})$ causes a leftward shift in the glutamate dose-response relationship in oocytes expressing GluRC $_{\mathrm{o}}$ (Fig. 6A,B). The apparent $\mathrm{EC}_{50}$ and Hill coefficient values for glutamate were, respectively, $36 \pm 6 \mu \mathrm{M}$ and 1.2 $(n=7)$ without PEPA, $10 \pm 1 \mu \mathrm{M}$ and $1.7(n=7)$ in the presence

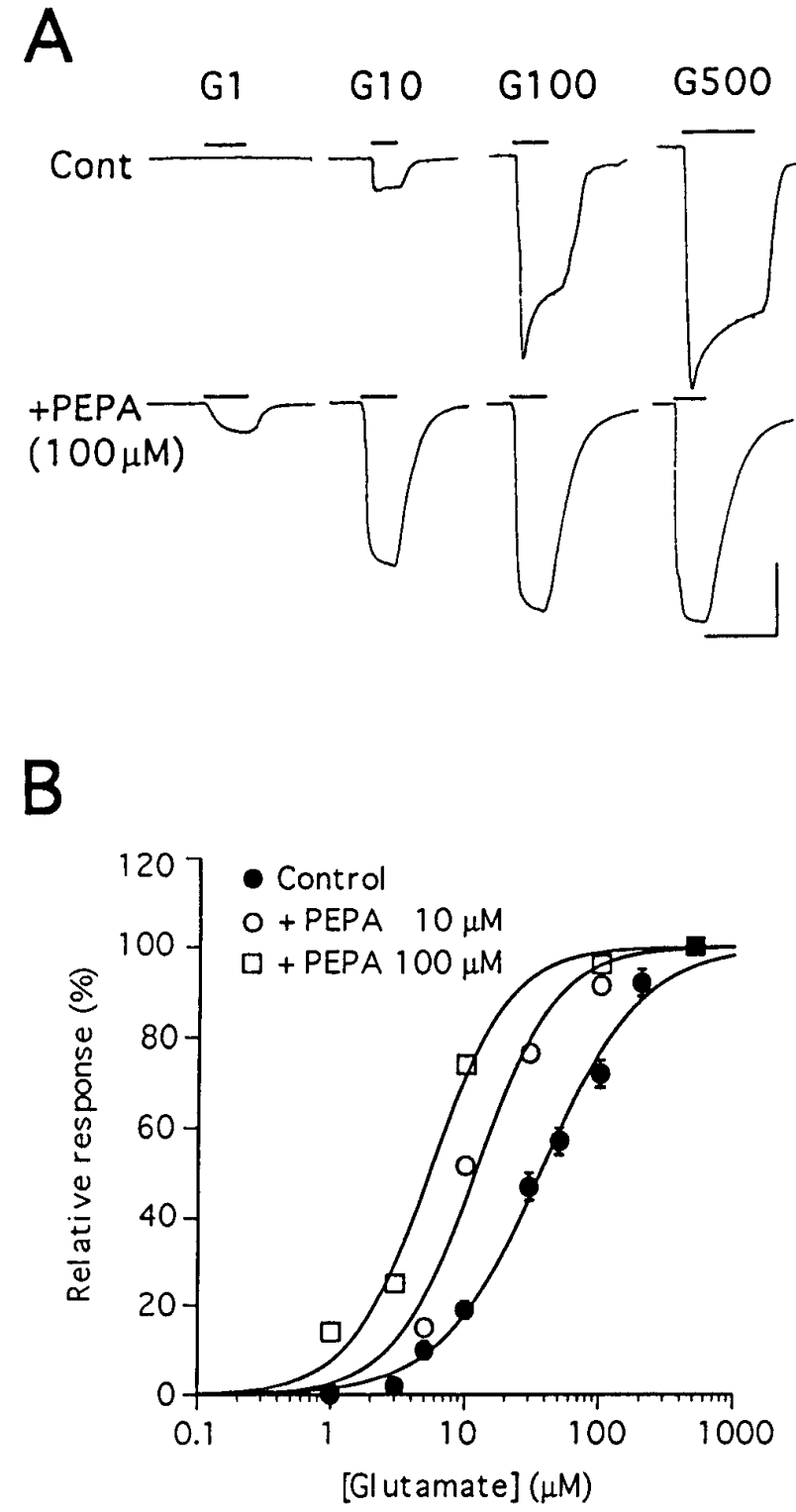

Figure 6. PEPA increases apparent affinity of $\mathrm{GluRC}_{\mathrm{o}}$ for glutamate. $A$, Responses to $1,10,100$, and $500 \mu \mathrm{M}$ glutamate in the absence (Cont) or presence $(+P E P A)$ of $100 \mu \mathrm{M}$ PEPA in oocytes expressing GluRC $_{\mathrm{o}}$. Calibration: $20 \mathrm{sec}$ for all traces, and $20 \mathrm{nA}$ for Cont and $250 \mathrm{nA}$ for $+P E P A$. $B$, Dose-response curves for glutamate in oocytes expressing GluRC $_{\mathrm{o}}$ without PEPA (Control) and with PEPA (10 or $\left.100 \mu \mathrm{M}\right)$. Glutamate responses are normalized to the response by $500 \mu \mathrm{M}$ glutamate in each oocyte. The theoretical curves indicate the best fit to the data according to the logistic function $I=100 /\left[1+\left(\mathrm{EC}_{50} /[G]\right)^{n}\right]$, in which $I$ is the relative response, and $[G]$ is the concentration of glutamate. Values are mean $\pm \operatorname{SEM}(n=4-7)$.

of $10 \mu \mathrm{M}$ PEPA, and $5 \pm 1 \mu \mathrm{M}$ and $1.7(n=4)$ in the presence of $100 \mu \mathrm{M}$ PEPA. Thus although flop-selective, the effects of PEPA on AMPA receptor affinity for glutamate resemble those of cyclothiazide as opposed to aniracetam.

\section{Weak potentiation by PEPA of kainate-evoked currents at AMPA receptors}

Figure 7 compares the actions of PEPA $(10 \mu \mathrm{M})$ on glutamateevoked $(100 \mu \mathrm{M})$ and kainate-evoked $(100 \mu \mathrm{M})$ currents in oocytes expressing the flip or flop splice variants of GluRC. In oocytes expressing $\mathrm{GluRC}_{\mathrm{o}}$, glutamate responses were much 
A Co

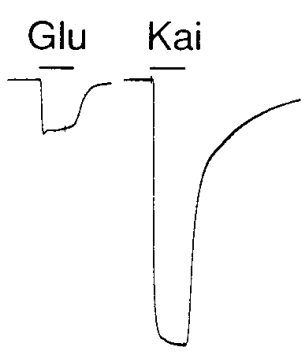

PEPA $10 \mu \mathrm{M}$

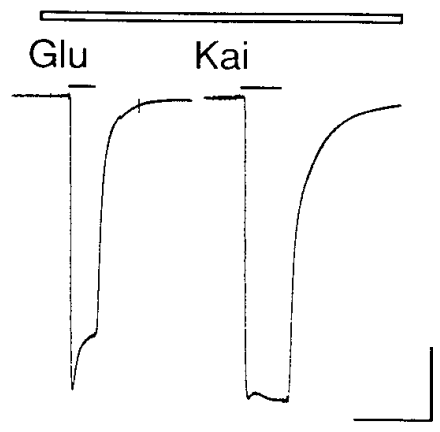

B Ci

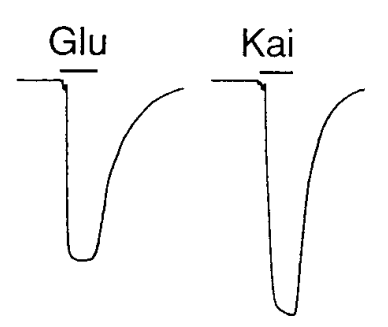

PEPA $10 \mu \mathrm{M}$

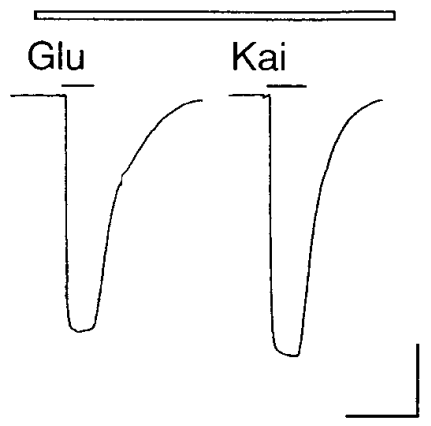

C

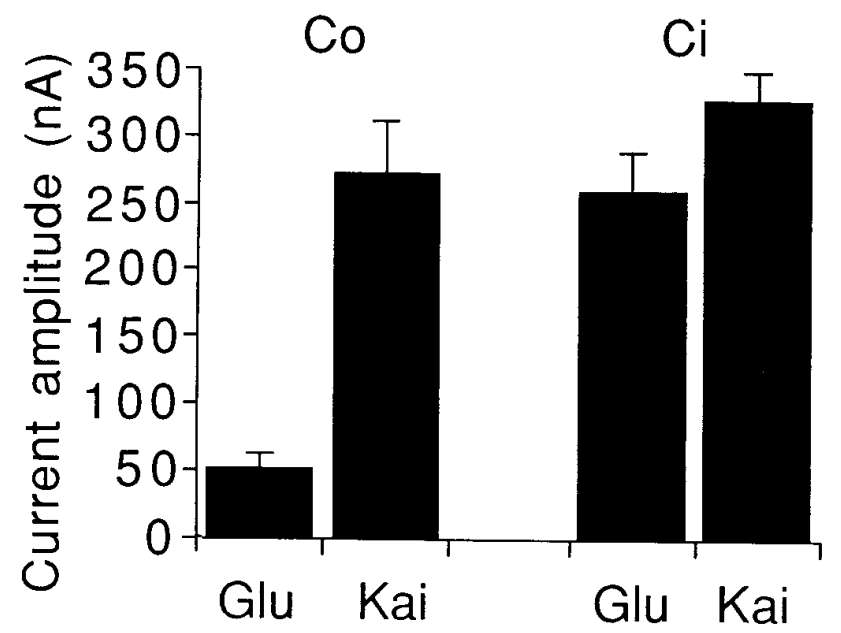

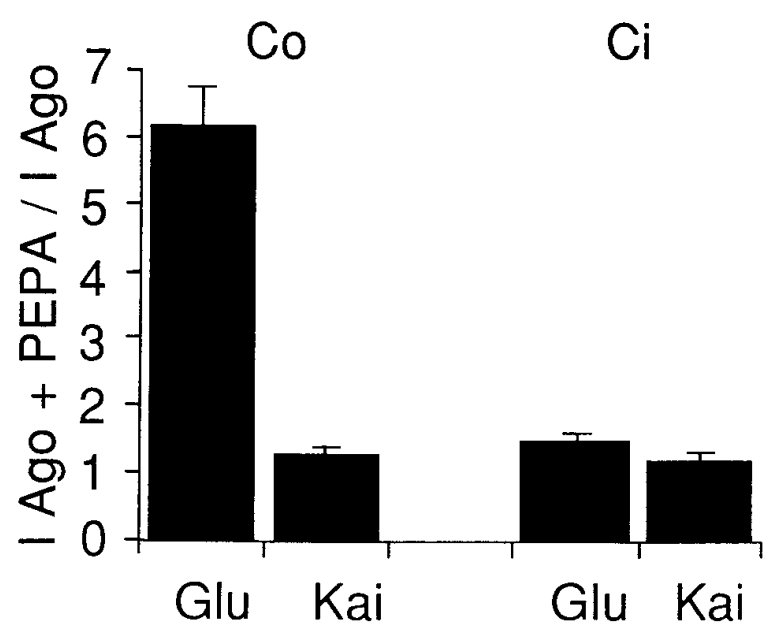

Figure 7. Activation of AMPA receptors by kainate shows weak potentiation by PEPA. Oocytes from a single preparation were injected with cRNA specific for GluRC or GluRC $_{\mathrm{i}}$ in parallel. $A, B$, Glutamate-evoked $(100 \mu \mathrm{M})$ and kainate-evoked $(100 \mu \mathrm{M})$ responses with or without PEPA $(10 \mu \mathrm{M})$ in oocytes expressing GluRC $(A)$ or GluRC $\mathrm{i}_{\mathrm{i}}(B)$. Calibration, $20 \mathrm{sec}$ and $100 \mathrm{nA}$. $C$, Comparison of the current amplitude (nA) for glutamate and kainate responses in oocytes expressing GluRC $(n=10)$ or $\mathrm{GluRC}_{\mathrm{i}}(n=8)$. D. Potentiation by $10 \mu \mathrm{M}$ PEPA of glutamate or kainate response in oocytes expressing $\operatorname{GluRC}_{\mathrm{o}}(n=10)$ or $\operatorname{GluRC}_{\mathrm{i}}(n=7)$. Values in $C$ and $D$ are mean $\pm \mathrm{SEM}$.

smaller than kainate responses (Fig. 7A,C), such that the ratio of their amplitudes $\left(I_{\text {glu }} / I_{\text {kai }}\right)$ was $0.19 \pm 0.02(n=10)$. This low value is attributable in part to stronger desensitization of responses to glutamate versus kainate at AMPA receptors (Patneau and Mayer, 1991; Patneau et al., 1993), a difference that is enhanced for flop versus flip splice variants (Lomeli et al., 1994; Mosbacher et al., 1994; Partin et al., 1994). Consistent with this, in oocytes expressing $\mathrm{GluRC}_{\mathrm{o}}$ the amplitude of glutamate responses $(53 \pm 11 \mathrm{nA})$ was much smaller than for oocytes expressing GluRC $_{\mathrm{i}}(258 \pm 27 \mathrm{nA})$, although the amplitude of equilibrium responses to kainate was similar for $\operatorname{GluRC}_{\mathrm{o}}(274 \pm 36 \mathrm{nA})$ and GluRC $_{\mathrm{i}}(325 \pm 22 \mathrm{nA})$. As a result, the $I_{\mathrm{glu}} / I_{\text {kai }}$ ratio for $\mathrm{GluRC}_{\mathrm{i}}$ $(0.77 \pm 0.04, n=7)$ was fourfold greater than for GluRC $_{\mathrm{o}}$.

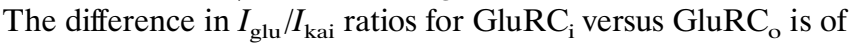
interest because PEPA potentiated glutamate responses for GluRC $_{\mathrm{o}}$ to a much greater extent than kainate responses (Fig. $7 A, D$ ), whereas for $\mathrm{GluRC}_{\mathrm{i}}$, although potentiation by PEPA was weaker than for GluRC $_{\mathrm{o}}$, the extent of potentiation was similar for both agonists (Fig. 7B,D). A similar agonist dependence for potentiation of AMPA receptor responses by aniracetam and cyclothiazide has been observed previously (Tsuzuki et al., 1992; Partin et al., 1994). These results suggest that PEPA potentiates AMPA receptor responses at least in part by reducing desensitization.

\section{PEPA suppresses AMPA receptor desensitization in HEK 293 cells}

A widely recognized limitation of the use of two-electrode voltage-clamp recording from oocytes is that it is impossible to apply solutions rapidly enough to resolve the very rapid desensitization exhibited by AMPA receptors. Analysis of the effects of drugs on AMPA receptor responses is confounded further by subunit and splice variant-specific differences in the amount of desensitization of control responses to glutamate, such that the amplitudes of equilibrium currents expressed by AMPA receptors vary with subunit composition (Lomeli et al., 1994; Mosbacher et al., 1994; Partin et al., 1994). One consequence of this would be that a receptor that normally desensitizes by $90 \%$ could be potentiated maximally only 10 -fold by block of desensitization, whereas a receptor that normally desensitizes by $99 \%$ could be potentiated 100-fold. Thus, the apparent selectivity of PEPA for GluRC and GluRD might not reflect simply a higher affinity of PEPA for these subunits, because the inherently stronger desen- 


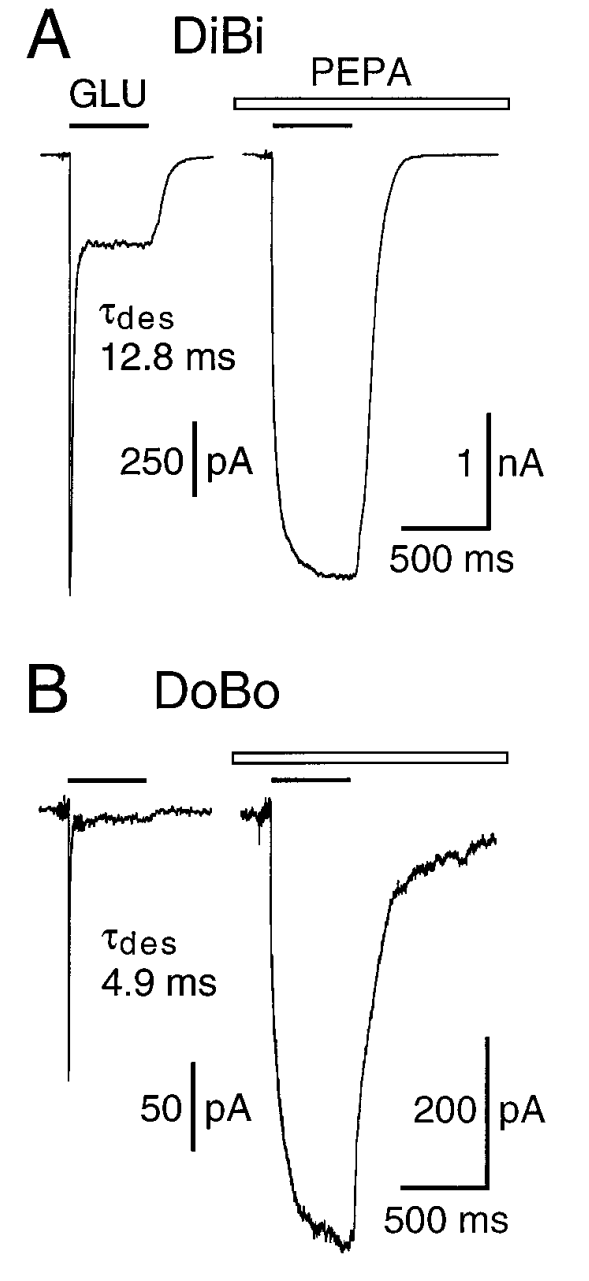

Figure 8. Potentiation by PEPA is correlated with desensitization of control responses to glutamate. $A$, Whole-cell responses to fast application of $3 \mathrm{~mm}$ glutamate in the absence (left) and presence (right) of $100 \mu \mathrm{M}$ PEPA recorded from HEK 293 cells transiently transfected with GluRB $\mathrm{D}_{\mathrm{i}}$; $B$, Similar responses for GluRB $_{0} D_{0}$. Control responses for GluRB $_{o} D_{o}$ display faster desensitization, smaller equilibrium currents, and greater equilibrium potentiation by PEPA than responses for GluR$\mathrm{B}_{\mathrm{i}} \mathrm{D}_{\mathrm{i}}$. A similar correlation between the extent of control desensitization and potentiation by PEPA was observed for all flip and flop subunit combinations examined, although the extent of the block of desensitization by $100 \mu \mathrm{M}$ PEPA varied among subunits. $C$, Concentration jump responses to PEPA reveal rapid onset and recovery from potentiation. $D$, Scatterplot correlating equilibrium potentiation by $100 \mu \mathrm{M}$ PEPA versus the steadystate amplitude of control responses to 3 mM glutamate; data for flip (0) and flop (O) splice variants are fit separately with logarithmic functions (dashed lines; points are mean $\pm \mathrm{SEM})$. Control responses to glutamate are smaller and potentiation by PEPA is greater for flop versus flip subunits. Heteromeric combinations of GluRA, GluRC, or GluRD with GluRB were transfected at a ratio of $1: 2$.
C $\mathrm{DiBi}$
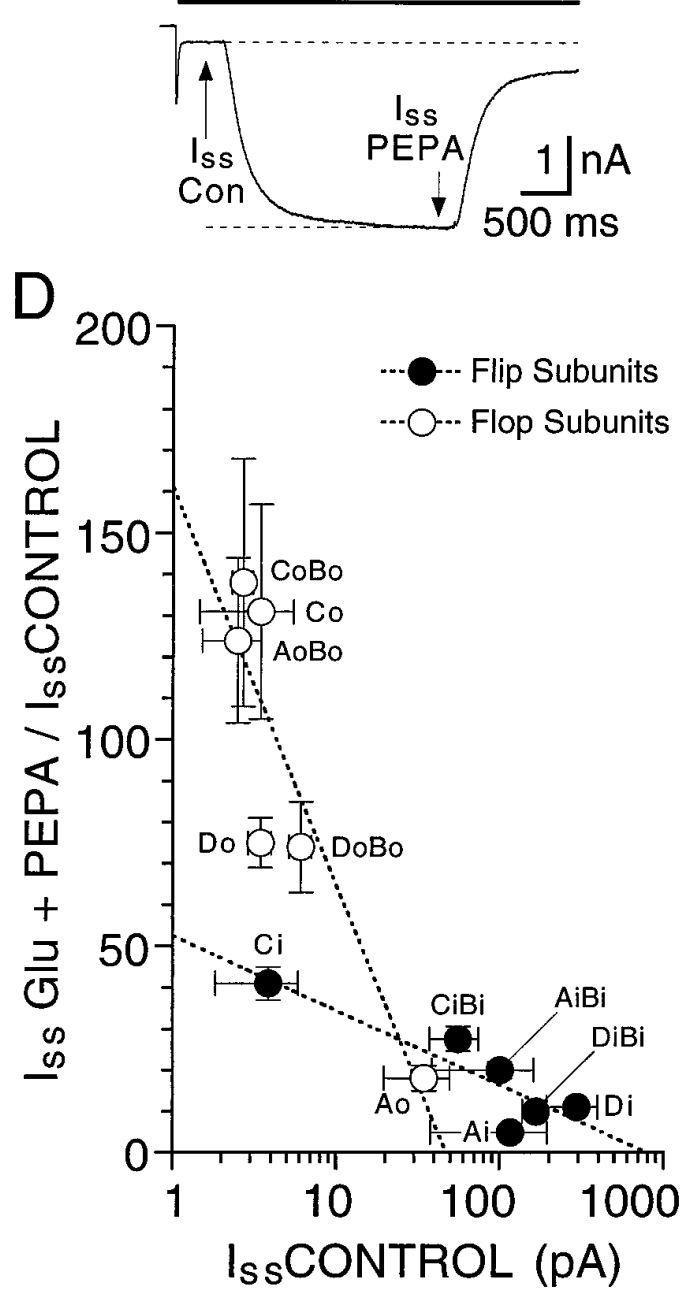

sitization for the flop splice variants of GluRC and GluRD (Lomeli et al., 1994; Mosbacher et al., 1994; Partin et al., 1994) also could increase potentiation of equilibrium responses to glutamate if the mechanism underlying potentiation by PEPA involved block of desensitization.

To address this issue, we used whole-cell recording with rapid perfusion to study recombinant AMPA receptor responses in transiently transfected HEK 293 cells. The kinetics of AMPA receptor desensitization was measured in response to concentration jump application of $3 \mathrm{~mm}$ glutamate in the absence or presence of $100 \mu \mathrm{M}$ PEPA (Fig. $8 A, B$ ). We also measured potentiation of equilibrium responses to glutamate in response to concentration jump application of PEPA (Fig. $8 C$ ). The combined results of such analysis reveal that, for subunit combinations for which PEPA fully blocks desensitization, differences in the extent of desensitization of control responses to glutamate indeed do appear to contribute to the extent of potentiation by PEPA. For example, although PEPA produced nearly complete block of desensitization for both GluRB $\mathrm{o}_{\mathrm{o}}$ and $\mathrm{GluRB}_{\mathrm{i}} \mathrm{D}_{\mathrm{i}}$ (Fig. 8A,B), potentiation of equilibrium responses to glutamate for these subunits suggested strong flop selectivity $\left(\right.$ GluRB $_{\mathrm{o}} \mathrm{D}_{\mathrm{o}}, 74 \pm 10.8$-fold potentiation; GluRB $_{\mathrm{i}} \mathrm{D}_{\mathrm{i}}, 9.7 \pm 1.2$-fold potentiation). Experiments with additional subunits provided further support for the hypothesis that the degree of potentiation by PEPA is determined in part by the extent of desensitization of control responses to glutamate; thus, as shown in Figure $8 D$, the magnitude of potentiation by PEPA was related inversely to the amplitude of equilibrium responses to glutamate in the absence of PEPA. Subunit combinations for which the onset of desensitization has been shown to occur extremely rapidly-GluRC , GluRD $_{\mathrm{o}}$, GluR$\mathrm{B}_{\mathrm{o}} \mathrm{C}_{\mathrm{o}}$, and GluRB $\mathrm{D}_{\mathrm{o}}$ (Mosbacher et al., 1994)—and that show the greatest extent of desensitization at equilibrium (Lomeli et al., 1994) showed much stronger potentiation by PEPA than did GluRA $_{i}$, GluRD $_{i}$, GluRA $_{i} B_{i}$, and GluRB $B_{i} D_{i}$, subunit combinations for which the onset of desensitization is relatively slow and that show less desensitization of control responses to glutamate (Lomeli et al., 1994; Mosbacher et al., 1994). The greater extent of potentiation by PEPA in HEK 293 cells (Fig. 8D) than in oocytes (see Fig. 4) possibly reflects difficulties in accurately measuring the equilibrium amplitude of control responses to glutamate in HEK 293 cells transfected with strongly desensitizing subunits. In Xenopus oocytes we noticed that the extent of potentiation by PEPA for $\mathrm{GluRC}_{\mathrm{o}}$ and $\mathrm{GluRD}_{\mathrm{o}}$ was related inversely to the amplitude of control responses to glutamate, possibly also reflecting inaccuracy in measuring the amplitude of control responses for these strongly desensitizing subunits.

The results shown in Figure 8 suggest that PEPA directly affects the process of desensitization and that subunit-specific 
Table 1. AMPA receptor kinetics in transfected HEK 293 cells

\begin{tabular}{|c|c|c|c|c|c|c|c|c|}
\hline Subunit(s) & $\tau_{\text {des }}($ Glu $)$ & $\begin{array}{l}\tau_{\text {des }} \\
(\text { Glu }+ \text { PEPA })\end{array}$ & $\begin{array}{l}\text { Desensitization } \\
\text { at } 2 \text { sec }(\%) \\
\text { (Glu+PEPA) }\end{array}$ & $\begin{array}{l}\text { Slowing of } \\
\text { desensitization } \\
\tau(\mathrm{Glu}+\mathrm{P}) / \tau(\mathrm{Glu})\end{array}$ & $\begin{array}{l}\text { Equilibrium } \\
\text { potentiation } \\
I(\mathrm{Glu}+\mathrm{P}) / I(\mathrm{Glu})\end{array}$ & PEPA $\tau_{\mathrm{ON}}$ & $\begin{array}{l}\text { PEPA } \tau_{\mathrm{OFF}} \\
\text { fast component }\end{array}$ & $\begin{array}{l}\tau_{\mathrm{OFF}} \\
\% \\
\text { fast }\end{array}$ \\
\hline $\mathrm{A}_{\mathrm{i}}$ & $7.98 \pm 0.48$ & $89 \pm 6$ & $84 \pm 3$ & 11.2 & $5 \pm 1$ & $122 \pm 14$ & $87 \pm 7$ & 87 \\
\hline $\mathrm{A}_{\mathrm{i}} \mathrm{B}_{\mathrm{i}}$ & $10.43 \pm 0.70$ & $244 \pm 19$ & $28 \pm 3$ & 23.4 & $20 \pm 2$ & $306 \pm 17$ & $140 \pm 8$ & 84 \\
\hline $\mathrm{A}_{\mathrm{O}}$ & $8.04 \pm 0.69$ & $252 \pm 13$ & $74 \pm 6$ & 31.3 & $18 \pm 3$ & $338 \pm 28$ & $176 \pm 15$ & 88 \\
\hline$A_{O} B_{O}$ & $6.43 \pm 0.45$ & N.D. & $1 \pm 1$ & $>300^{* *}$ & $124 \pm 20$ & $521 \pm 39$ & $222 \pm 15$ & 79 \\
\hline $\mathrm{C}_{\mathrm{i}}$ & $9.92 \pm 1.20$ & $300 \pm 25$ & $45 \pm 4$ & 30.2 & $41 \pm 4$ & $253 \pm 12$ & $156 \pm 20$ & 85 \\
\hline $\mathrm{B}_{\mathrm{i}} \mathrm{C}_{\mathrm{i}}$ & $14.40 \pm 0.76$ & N.D. & $6 \pm 2$ & $>140^{* *}$ & $28 \pm 3$ & $257 \pm 24$ & $153 \pm 8$ & 93 \\
\hline $\mathrm{C}_{\mathrm{O}}$ & $3.28 \pm 0.34$ & $314 \pm 18$ & $47 \pm 4$ & 95.7 & $131 \pm 26$ & $308 \pm 21$ & $193 \pm 16$ & 87 \\
\hline $\mathrm{B}_{\mathrm{O}} \mathrm{C}_{\mathrm{O}}$ & $4.39 \pm 0.38$ & $564 \pm 45^{*}$ & $15 \pm 2^{*}$ & $>300^{* *}$ & $138 \pm 30$ & $475 \pm 25$ & $226 \pm 10$ & 89 \\
\hline $\mathrm{D}_{\mathrm{i}}$ & $9.15 \pm 0.56$ & $365 \pm 22$ & $28 \pm 5$ & 39.9 & $11 \pm 1$ & $372 \pm 27$ & $201 \pm 9$ & 65 \\
\hline $\mathrm{B}_{\mathrm{i}} \mathrm{D}_{\mathrm{i}}$ & $14.15 \pm 1.09$ & N.D. & $4 \pm 3$ & $>140^{* *}$ & $10 \pm 1$ & $335 \pm 47$ & $192 \pm 11$ & 73 \\
\hline $\mathrm{D}_{\mathrm{O}}$ & $3.11 \pm(n=2$ of 9$) \#$ & N.D. & $7 \pm 1$ & $>600^{* *}$ & $75 \pm 6$ & $417 \pm 29$ & $237 \pm 9$ & 85 \\
\hline $\mathrm{B}_{\mathrm{O}} \mathrm{D}_{\mathrm{O}}$ & $6.46 \pm 0.65$ & N.D. & $5 \pm 1$ & $>300^{* *}$ & $74 \pm 11$ & $571 \pm 50$ & $267 \pm 11$ & 70 \\
\hline
\end{tabular}

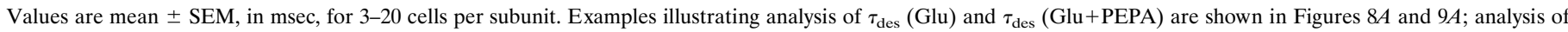

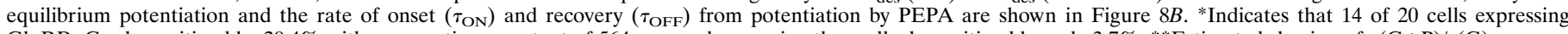

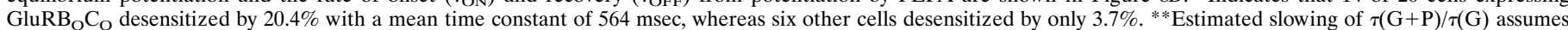

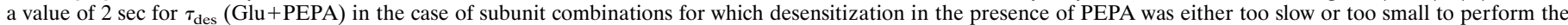
exponential analysis accurately. \#Indicates that for only two of nine cells were control responses to glutamate large enough to estimate $\tau_{\text {des }}$ accurately.

differences in the magnitude of PEPA potentiation are likely to reflect both the intrinsic desensitization properties of individual subunits as well as possible differences in affinity for PEPA. Although for some subunits (e.g., GluRC $\mathrm{o}_{\mathrm{o}}$ and $\mathrm{GluRD}_{\mathrm{o}}$ ) the rate of desensitization of control responses to glutamate was too rapid to be measured accurately by whole-cell recording, for all subunit combinations tested both the rate of onset and amount of desensitization were strongly attenuated by PEPA, making it relatively easy to compare differences in desensitization kinetics among subunits in the presence of PEPA (Table 1).

The results of such an analysis are shown in Figure 9 and emphasize both the selective modulation by PEPA of AMPA receptor flop splice variants as well as subunit-selective effects of PEPA. Thus, even for GluRA, the least sensitive subunit examined for which desensitization remained pronounced in the presence of PEPA for both flip and flop splice variants (Fig. 9A), the time constant of onset of desensitization for GluRA ${ }_{\mathrm{o}}\left(\tau_{\text {control }}\right.$, $8.0 \pm 0.4 \mathrm{msec} ; \tau_{\mathrm{PEPA}}, 252 \pm 13 \mathrm{msec} ; n=14$ ) was slowed by 100 $\mu \mathrm{M}$ PEPA nearly three times more than for GluRA $\left(\tau_{\text {control }}\right.$, $\left.8.0 \pm 0.5 \mathrm{msec} ; \tau_{\text {PEPA }}, 89 \pm 6 \mathrm{msec} ; n=11\right)$. In addition, a residual fast-desensitizing component of time constant identical to that for control responses to glutamate and that accounted for $27 \pm 4 \%$ of the decay in the presence of $100 \mu \mathrm{M}$ PEPA suggests that for GluRA $A_{i}$ the binding of PEPA is not saturated at $100 \mu \mathrm{M}$, whereas for GluRA $A_{o}$ desensitization in the presence of $100 \mu \mathrm{M}$ PEPA was well fit by a single exponential, suggesting that binding of PEPA to GluRA $A_{o}$ is saturated at $100 \mu \mathrm{M}$. Although the flopselective action of PEPA is indicated further by the complete block of desensitization by $100 \mu \mathrm{M}$ PEPA for GluRD $\mathrm{O}_{\mathrm{o}}$ and

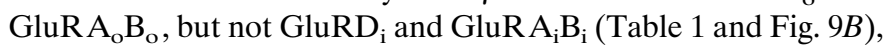
for other subunits $\left(G_{l u R C}\right.$ vs GluRC $_{i}$ and GluRB $D_{o}$ vs GluR$\left.\mathrm{B}_{\mathrm{i}} \mathrm{D}_{\mathrm{i}}\right)$ there was no clear difference in the extent of attenuation of desensitization by $100 \mu \mathrm{M}$ PEPA between flip and flop splice variants; in contrast to the similar degree of equilibrium potentiation for these subunits (Table 1), the subunit dependence for slowing of desensitization followed the rank order GluRD > GluRC $\gg$ GluRA (Fig. 9).

The effects of PEPA were enhanced further by heteromerization with the corresponding flip or flop isoforms of GluRB, and the current observed after a 2 sec application of GLU+PEPA approached $100 \%$ of peak in cells expressing GluR $A_{o} B_{o}$, GluR$\mathrm{B}_{\mathrm{i}} \mathrm{C}_{\mathrm{i}}$, GluRB $_{\mathrm{i}} \mathrm{D}_{\mathrm{i}}$, and GluRB $\mathrm{D}_{\mathrm{o}}$; these subunit combinations, together with GluRD ${ }_{o}$, therefore were classified as effectively "nondesensitizing" within the limits of the current protocol (Fig. $9 B)$. In an attempt to differentiate among subunits that effectively were nondesensitizing during $2 \mathrm{sec}$ applications of PEPA+GLU, we also measured the kinetics of onset of $\left(\tau_{\text {on }}\right)$ and recovery from $\left(\tau_{\text {off }}\right)$ potentiation by PEPA in the continuous presence of glutamate (Fig. $8 C$, Table 1). Such experiments revealed responses to PEPA with kinetics more complex than that predicted by a simple model in which binding of PEPA blocks desensitization, because the response to removal of PEPA frequently showed both fast and slow components of decay of potentiation (Fig. 8C). In addition, for flop subunits responses to glutamate in the presence of PEPA tended to show fast and slow components of activation and deactivation (Figs. $8 B, 9 A$ ), indicating that the mechanism or mechanisms of action of PEPA are likely to be complex. Within these limitations and assuming that $\tau_{\text {off }}$ approximates the inverse rate constant for dissociation of PEPA and that the rate constant for binding of PEPA does not differ among subunits, analysis that uses the protocol shown in Figure $8 C$ gives an indirect measure of subunit-dependent differences in affinity for PEPA (Table 1). In cells expressing AMPA receptor flop isoforms, values for $\tau_{\text {off }}$ in response to removal of PEPA were consistently slower than for the corresponding flip isoforms, suggesting a higher affinity of flop receptors for PEPA. However, between the fastest (GluRA $A_{i}$; $\left.\tau_{\text {off }}, 87 \pm 7 \mathrm{msec}\right)$ and slowest responding subunits $\left(\right.$ GluRD $_{\mathrm{o}} ; \tau_{\text {off }}$, $237 \pm 9 \mathrm{msec}$ ) there was only a threefold range in kinetics of recovery from potentiation, indicating that additional mechanisms must underlie subunit selective modulation by PEPA. Especially interesting is the comparison for responses to $100 \mu \mathrm{M}$ cyclothiazide recorded with similar protocols (Patneau et al., 1993; Partin et al., 1994), which reveal that the onset of potentiation by $100 \mu \mathrm{M}$ PEPA develops $\sim 50-100$ times faster than for cyclothiazide, although both drugs produce nearly complete block of desensitization for selected subunit combinations. The kinetics of recovery from potentiation by PEPA (Table 1) was also much 
A

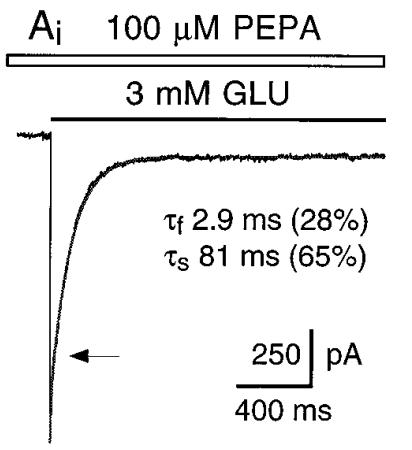

$A_{\circ}$

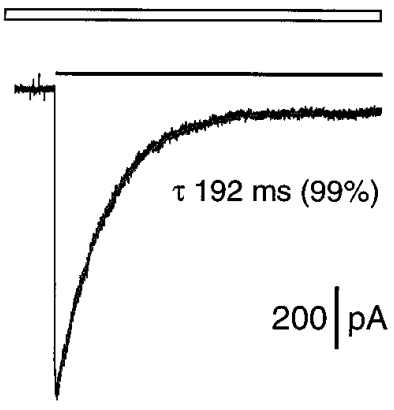

$A_{i} B_{i}$

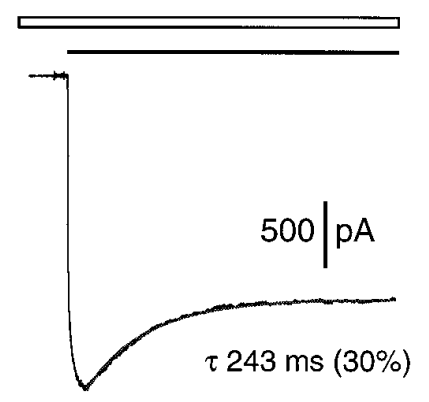

$\mathrm{A}_{0} \mathrm{~B}_{\mathrm{o}}$

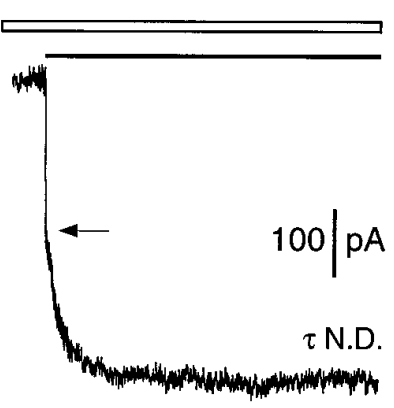

B

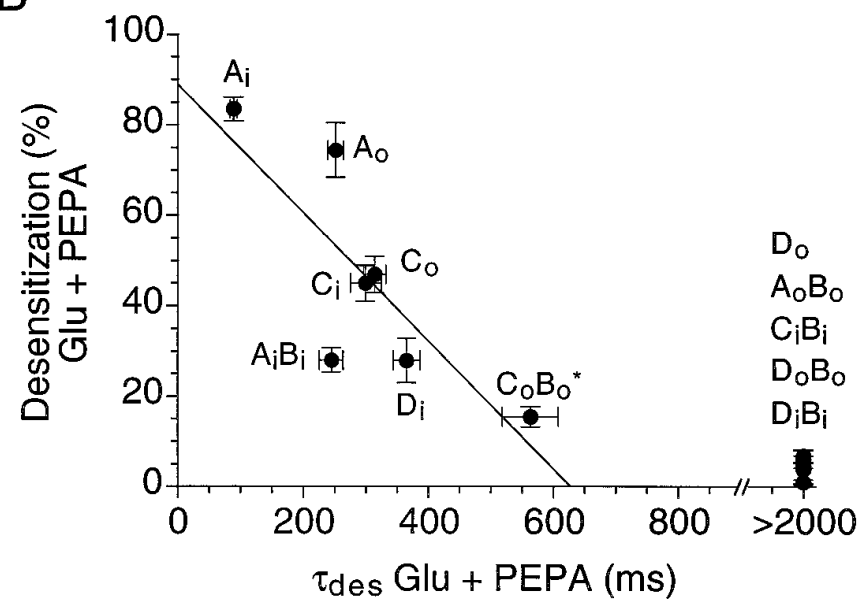

Figure 9. Block of desensitization by PEPA shows subunit and splicevariant selectivity. $A$, Whole-cell responses to fast application of $3 \mathrm{~mm}$ glutamate applied in the presence of $100 \mu \mathrm{M}$ PEPA and recorded from transiently transfected HEK 293 cells expressing GluRA $A_{i}$, GluRA $A_{o}$, Glu$\mathrm{RA}_{\mathrm{i}} \mathrm{B}_{\mathrm{i}}$, or GluRA $\mathrm{A}_{\mathrm{o}}$, as indicated. Lines drawn through the data points show the onset of desensitization fit with exponential functions, as described in Materials and Methods. For GluRA $A_{i}$ and GluRA $\mathrm{A}_{\mathrm{o}}$, arrows indicate transitions between fast and slow components of the response to glutamate; the slow component of activation seen for GluRA $\mathrm{B}_{\mathrm{o}}$ was typical of responses for subunit combinations strongly modulated by PEPA. Values for $\tau_{\text {des }}$ (mean \pm SEM, $n=3-14$ cells) were $89 \pm 6$ msec $\left(\right.$ GluRA $\left._{i}\right)$, $252 \pm 13 \mathrm{msec}\left(\right.$ GluRA $\left._{\mathrm{o}}\right)$, and $244 \pm 19 \mathrm{msec}\left(\right.$ GluRA $\left._{\mathrm{i}} \mathrm{B}_{\mathrm{i}}\right)$. B, Summary of results from transfections with additional AMPA receptor flip and flop splice variants for which the extent and rate of onset of desensitization in the presence of $100 \mu \mathrm{M}$ PEPA were estimated as shown in $A$. Star indicates that for GluRC $\mathrm{C}_{\mathrm{o}} \mathrm{B}_{\mathrm{o}}$ only 14 of 20 cells gave sufficiently strongly desensitizing responses to estimate the rate of onset of desensitization; for $\mathrm{GluRD}_{\mathrm{o}}$, GluR $A_{o} B_{o}, G_{l u R C} B_{i}$, and GluRD $B_{o}$, which gave weakly or nondesensitizing responses for which it was not possible to fit exponentials accurately, the time constant of desensitization is given as $>2000 \mathrm{msec}$. faster than that for recovery from potentiation by cyclothiazide (Patneau et al., 1993; Partin et al., 1994).

\section{DISCUSSION}

Our results show that PEPA is a selective and potent modulator of AMPA subtype glutamate receptors, with preferential activity at flop splice variants. PEPA potentiates glutamate-evoked currents by slowing the rate of onset of desensitization and by increasing the apparent affinity of AMPA receptors for agonist. It is possible that PEPA also slows deactivation, but this was not tested in the present experiments. The effects of PEPA were much stronger for GluRC and GluRD versus GluR A, most likely reflecting either subunit-dependent differences in affinity and/or stronger desensitization of control responses to glutamate for GluRC and GluRD versus GluRA.

\section{PEPA versus aniracetam}

Comparison with previous work (Johansen et al., 1995; Partin et al., 1996) suggests that PEPA and aniracetam have similar subunit and splice-variant selectivity; however, PEPA is considerably more potent than aniracetam in potentiating AMPA receptor currents. In agreement with this, concentrations in excess of 1-5 $\mathrm{mM}$ aniracetam are required for strong potentiation of AMPA receptor currents in oocytes (Tsuzuki et al., 1992; Johansen et al., 1995); in fact, saturation of the dose-response relationship cannot be achieved because of the low affinity and limited solubility of aniracetam in physiological solutions. In contrast, PEPA effectively potentiates AMPA receptor responses at 10-200 $\mu \mathrm{M}$ concentrations. It was reported that $1 \mathrm{~mm}$ aniracetam potentiates glutamate-evoked currents $\sim 2.5$-fold in oocytes expressing GluRA o $_{\text {o }}$ (Tsuzuki et al., 1992), whereas a fivefold lower concentration of PEPA $(200 \mu \mathrm{M})$ potentiates GluRA $A_{o}$ responses eightfold (Fig. 4). Another study reported eightfold potentiation by 5 $m \mathrm{~m}$ aniracetam for oocytes expressing GluR $\mathrm{A}_{\mathrm{i}} \mathrm{B}_{\mathrm{i}}$ or $\operatorname{GluRB}_{\mathrm{i}} \mathrm{D}_{\mathrm{i}}$, 17-fold potentiation for GluR $A_{o} B_{o}$, and 77-fold potentiation for GluRB $_{\mathrm{o}} \mathrm{D}_{\mathrm{o}}$ (Johansen et al., 1995); we have found comparable amounts of potentiation by 100-200 $\mu \mathrm{M}$ PEPA in the present study. Another remarkable difference between PEPA and aniracetam is their apparent efficacy for block of desensitization. Although limited solubility makes it impossible to assess the maximal effect of aniracetam, PEPA appears to have a much greater effect on slowing desensitization. In rapid perfusion experiments on HEK 293 cells expressing GluRA $A_{i}$ or GluRA $A_{o}$, the rate of onset of desensitization $\left(\tau_{\text {des }}\right)$ in the presence of $5 \mathrm{~mm}$ aniracetam, 20 and $32 \mathrm{msec}$, respectively (Partin et al., 1996), was much faster than in the presence of $100 \mu \mathrm{M}$ PEPA, 89 and $252 \mathrm{msec}$, respectively (Fig. 9).

\section{PEPA versus cyclothiazide}

In the present study PEPA $(25 \mu \mathrm{M})$ was found to potentiate glutamate responses for $\mathrm{GluRC}_{\mathrm{o}}$ to a much greater extent than the same concentration of cyclothiazide, whereas the reverse was true for GluRC $_{\mathrm{i}}$ (see Fig. 2C). PEPA and cyclothiazide appear to have similar potency but opposite splice-variant selectivity; whereas PEPA preferentially modulates flop receptors, cyclothiazide has been shown to prefer flip isoforms (Partin et al., 1994). However, in rapid perfusion experiments on HEK 293 cells expressing GluRC, the extent and rate of onset of desensitization of responses to glutamate in the presence of $100 \mu \mathrm{M}$ PEPA were similar for $\mathrm{GluRC}_{\mathrm{o}}\left(\tau_{\mathrm{des}}, 314 \pm 18 \mathrm{msec}\right)$ and $\mathrm{GluRC}_{\mathrm{i}}\left(\tau_{\mathrm{des}}\right.$, 
$300 \pm 25 \mathrm{msec}$ ), indicating that the flop selectivity of PEPA for potentiation of GluRC equilibrium responses to glutamate most likely reflects differences in the extent of desensitization of control responses to glutamate. In contrast, for GluRA $A_{o}$ the time constant of desensitization in the presence of $100 \mu \mathrm{M}$ PEPA $(252 \pm 13 \mathrm{msec})$ was much slower than for GluRA ${ }_{\mathrm{i}}\left(\tau_{\mathrm{des}}, 89 \pm 6\right.$ msec), whereas for $100 \mu \mathrm{M}$ cyclothiazide desensitization was blocked almost fully for GluRA $A_{i}$ but remained pronounced for GluRA $_{o}$ (Partin et al., 1994). The flop selectivity for modulation of desensitization by PEPA was modified by coassembly with GluRB; thus, almost complete block of desensitization by $100 \mu \mathrm{M}$ PEPA was observed for the flop splice-variant combinations GluRB $_{\mathrm{o}} \mathrm{C}_{\mathrm{o}}$ and $\mathrm{GluRB}_{\mathrm{o}} \mathrm{D}_{\mathrm{o}}$ but also for the corresponding flip splice-variant combinations GluRB $\mathrm{C}_{\mathrm{i}}$ and $\mathrm{GluRB}_{\mathrm{i}} \mathrm{D}_{\mathrm{i}}$. For Glu$\mathrm{RA}_{\mathrm{i}}$ and GluRA $\mathrm{A}_{\mathrm{o}}$, coassembly with the corresponding flip and flop splice variants of GluRB also increased the extent of block of desensitization by PEPA, although the effect was greater for GluRA $_{o} B_{o}$ than for GluRA $A_{i} B_{i}$ (Fig. 9).

\section{Mechanism of action of PEPA}

A characteristic feature of allosteric modulation by PEPA, which is common also to aniracetam and cyclothiazide, is that each drug potentiates AMPA receptor currents by suppressing desensitization. However, it has been proposed recently that aniracetam and cyclothiazide suppress desensitization by different mechanisms (Partin et al., 1996). Kinetic modeling of the rapid deactivation and desensitization kinetics of GluR $A_{i}$ and GluRA $A_{o}$ suggests that aniracetam slows the rate of channel closing, indirectly slowing the onset of desensitization, whereas cyclothiazide has a direct effect on the rate constant of desensitization and, in addition, stabilizes agonist-bound closed states, thus increasing agonist affinity and slowing deactivation. Whether this model is sufficient to explain the behavior of other subunits or of heteromeric subunit combinations remains to be determined. Although additional experiments are required to develop a kinetic model for the action of PEPA, our results show that PEPA does not behave exactly like aniracetam, because for some subunits PEPA completely prevented desensitization. If this were attributable exclusively to slowing of deactivation, as modeled for aniracetam modulation of GluRA (Partin et al., 1996), we would expect a considerably more pronounced slowing of the current decay after removal of agonist than was observed in our experiments (Fig. 8). Also, PEPA caused a leftward shift in the agonist dose-response relationship for $\mathrm{GluRC}_{\mathrm{o}}$ (Fig. 6) reminiscent of the action of cyclothiazide, but not aniracetam. A detailed analysis of deactivation kinetics in the presence of PEPA and experiments designed to resolve the origin of the slow onset of responses to glutamate in the presence of PEPA (Figs. 8, 9) will be necessary to understand how modulation by PEPA differs from that produced by aniracetam and cyclothiazide.

\section{Drug design and receptor structure-function analysis}

When the chemical structures are compared among aniracetam, cyclothiazide, and PEPA (see Fig. 1), no obvious features common to all three drugs are seen. There is, however, a sulfonylamino group (-SO $\left.\mathrm{SO}_{2} \mathrm{NH}-\right)$ common to PEPA, cyclothiazide, and other benzothiadiazines that has been shown to suppress AMPA receptor desensitization (Bertolino et al., 1993; Yamada and Tang, 1993). The fact that this functional group is not found in aniracetam suggests that it might be important for coupling drug binding to modulation of desensitization versus channel-gating kinetics.

Although the actions of aniracetam and cyclothiazide are different, it has been shown previously that modulation by both drugs is sensitive to a single amino acid residue in the flip/flop domain (Partin et al., 1995). This position contains a serine residue in flip splice variants, an asparagine residue in flop splice variants, and a glutamine residue at the equivalent site in cyclothiazide-insensitive kainate receptors (S/N/Q site). Exchange of the serine and asparagine residues by site-directed mutagenesis (GluR $\mathrm{A}_{\mathrm{i}} \mathrm{S} 750 \mathrm{~N}$ and GluR $\mathrm{A}_{\mathrm{o}} \mathrm{N750S}$ ) is sufficient to exchange flip-like and flop-like modulation by aniracetam and cyclothiazide (Partin et al., 1995, 1996). Preliminary observations in HEK 293 cells expressing GluRA $\mathrm{A}_{\mathrm{i}} \mathrm{S} 750 \mathrm{~N}$ and in oocytes expressing the corresponding GluRC $\mathrm{C}_{\mathrm{i}}$ mutant $\mathrm{S} 758 \mathrm{~N}$ confirm that this site also is involved in the action of PEPA and that the exchange of serine for asparagine is sufficient to convert flip-like to flop-like modulation (data not shown). Furthermore, in HEK 293 cells sensitivity to cyclothiazide, but not PEPA or aniracetam, is abolished for the mutant GluR $\mathrm{A}_{\mathrm{i}} \mathrm{S} 750 \mathrm{Q}$. It remains to be determined, however, whether the $\mathrm{S} / \mathrm{N} / \mathrm{Q}$ site contributes to a binding site for these drugs or is involved in directing a conformational transition on which all three drugs converge.

Recently, a three-dimensional model for non-NMDA glutamate receptors has been proposed (Sutcliffe et al., 1996). This model proposes a disulfide bond linking two highly conserved Cys residues, which are located in a large extracellular loop between the M3 and M4 domains (Hollmann et al., 1994; Stern-Bach et al., 1994; Bennett and Dingledine, 1995). One of these Cys residues is located in the S2 domain, one of two putative agonist-binding domains that show structural homology with bacterial periplasmic lysine/arginine/ornithine binding protein (LAOBP; Stern-Bach et al., 1994). The other is located in the flip/flop segment, which is implicated in deactivation and desensitization (Mosbacher et al., 1994; Partin et al., 1996). Formation of a disulfide bond between these residues may be important for the actions of cyclothiazide and PEPA, because these drugs affect apparent affinity for both agonist and channel kinetics.

\section{Pharmacological and physiological significance of allosteric modulation}

Because of its strong preference for flip isoforms, cyclothiazide has been used to infer the splice-variant composition of native AMPA receptors in subpopulations of hippocampal neurons (Fleck et al., 1996). Cyclothiazide also has been useful in examining the relationship between desensitization and synaptic efficacy. Similarities in the rate of AMPA receptor desensitization and the rate of synaptic current decay in certain neuronal populations suggest that at some synapses the rapid onset of AMPA receptor desensitization may serve to limit the duration of the excitatory postsynaptic response and/or induce postsynaptic depression (Trussell and Fischbach, 1989; Otis et al., 1996). However, although both cyclothiazide (Trussell et al., 1993; Yamada and Tang, 1993; Raman et al., 1994) and aniracetam (Isaacson and Nicoll, 1991; Tang et al., 1991; Vyklicky et al., 1991; Hestrin, 1992) have been shown to enhance the peak amplitude and prolong the duration of excitatory postsynaptic currents, at many synapses this most likely results from a combination of presynaptic effects and a reduced rate of channel closing rather than from block of desensitization (Hestrin, 1992; Diamond and Jahr, 1995). For this reason further work to establish the mechanism or 
mechanisms by which PEPA modulates AMPA receptors will be required before it would be wise to use this drug to investigate the role of AMPA receptor subtypes in synaptic transmission. In addition, it should be noted that, because PEPA was synthesized in the process of developing thromboxane A2 antagonists, it is possible that it could act on targets distinct from glutamate receptors; we established that PEPA is selective for AMPA versus kainate and NMDA receptors, but its effects on other receptor species have not yet been investigated.

Other studies have suggested that the memory- and cognitionenhancing properties of the pyrrolidinone- and benzothiadiazinecontaining drugs are related to their ability to enhance synaptic transmission via modulation of AMPA receptor gating (Arai et al., 1994; Staubli et al., 1994a,b; Johansen et al., 1995; Zivkovic et al., 1995). In this regard, PEPA may be useful as a pharmacological tool and could provide new clues in the search for novel and more potent drugs affecting memory and cognition.

\section{REFERENCES}

Arai A, Kessler M, Xiao P, Ambros-Ingerson J, Rogers G, Lynch G (1994) A centrally active drug that modulates AMPA receptor gated currents. Brain Res 638:343-346.

Bennett JA, Dingledine R (1995) Topology profile for a glutamate receptor: three transmembrane domains and a channel-lining re-entrant membrane loop. Neuron 14:373-384.

Bertolino M, Baraldi M, Parenti C, Braghiroli D, DiBella M, Vicini S, Costa E (1993) Modulation of AMPA/kainate receptors by analogues of diazoxide and cyclothiazide in thin slices of rat hippocampus. Receptors Channels 1:267-278.

Boulter J, Hollmann M, O'Shea-Greenfield A, Hartley M, Deneris E, Maron C, Heinemann S (1990) Molecular cloning and functional expression of glutamate receptor subunit genes. Science 249:1033-1037.

Bowie D, Mayer ML (1995) Inward rectification of both AMPA and kainate subtype glutamate receptors generated by polyamine-mediated ion channel block. Neuron 15:453-462.

Chen C, Okayama H (1987) High-efficiency transformation of mammalian cells by plasmid DNA. Mol Cell Biol 7:2745-2752.

Diamond JS, Jahr CE (1995) Asynchronous release of synaptic vesicles determines the time course of the AMPA receptor-mediated EPSC. Neuron 15:1097-1107.

Ferrer-Montiel AV, Montal M (1996) Pentameric subunit stoichiometry of a neuronal glutamate receptor. Proc Natl Acad Sci USA 93:2741-2744.

Fleck MW, Bähring R, Patneau DK, Mayer ML (1996) AMPA receptor heterogeneity in rat hippocampal neurons revealed by differential sensitivity to cyclothiazide. J Neurophysiol 75:2322-2333.

Hestrin S (1992) Activation and desensitization of glutamate-activated channels mediating fast excitatory synaptic currents in the visual cortex. Neuron 9:991-999.

Hollmann M, O'Shea-Greenfield A, Rogers SW, Heinemann S (1989) Cloning by functional expression of a member of the glutamate receptor family. Nature 342:643-648.

Hollmann M, Hartley M, Heinemann S (1991) $\mathrm{Ca}^{2+}$ permeability of KA-AMPA-gated glutamate receptor channels depends on subunit composition. Science 252:851-853.

Hollmann M, Maron C, Heinemann S (1994) $N$-glycosylation site tagging suggests a three transmembrane domain topology for the glutamate receptor GluR1. Neuron 13:1331-1343.

Hume RI, Dingledine R, Heinemann SF (1991) Identification of a site in glutamate receptor subunits that controls calcium permeability. Science 253:1028-1031.

Isaacson JS, Nicoll RA (1991) Aniracetam reduces glutamate receptor desensitization and slows the decay of fast excitatory synaptic currents in the hippocampus. Proc Natl Acad Sci USA 88:10936-10940.

Ito I, Tanabe S, Kohda A, Sugiyama H (1990) Allosteric potentiation of quisqualate receptors by a nootropic drug aniracetam. J Physiol (Lond) 424:533-543.

Johansen TH, Chaudhary A, Verdoorn TA (1995) Interactions among GYKI-52466, cyclothiazide, and aniracetam at recombinant AMPA and kainate receptors. Mol Pharmacol 48:946-955.

Keinänen K, Wisden W, Sommer B, Werner P, Herb A, Verdoorn TA,
Sakmann B, Seeburg PH (1990) A family of AMPA-selective glutamate receptors. Science 249:556-560.

Lomeli H, Mosbacher J, Melcher T, Höger T, Geiger JRP, Kuner T, Monyer H, Higuchi M, Bach A, Seeburg PH (1994) Control of kinetic properties of AMPA receptor channels by nuclear RNA editing. Science 266:1709-1713.

Matsui T, Sekiguchi M, Hashimoto A, Tomita U, Nishikawa T, Wada K (1995) Functional comparison of D-serine and glycine in rodents: the effect on cloned NMDA receptors and the extracellular concentration. J Neurochem 65:454-458.

Monyer H, Seeburg PH, Wisden W (1991) Glutamate-operated channels: developmentally early and mature forms arise by alternative splicing. Neuron 6:799-810.

Mosbacher J, Schoepfer R, Monyer H, Burnashev N, Seeburg P, Ruppersberg JP (1994) A molecular determinant for submillisecond desensitization in glutamate receptors. Science 266:1059-1062.

Otis T, Zhang S, Trussell LO (1996) Direct measurement of AMPA receptor desensitization induced by glutamatergic synaptic transmission. J Neurosci 16:7496-7504.

Partin KM, Patneau DK, Mayer ML (1994) Cyclothiazide differentially modulates desensitization of AMPA receptor splice variants. Mol Pharmacol 46:129-138.

Partin KM, Bowie D, Mayer ML (1995) Structural determinants of allosteric regulation in alternatively spliced AMPA receptors. Neuron 14:833-843.

Partin KM, Fleck MW, Mayer ML (1996) AMPA receptor flip/flop mutants affecting deactivation, desensitization, and modulation by cyclothiazide, aniracetam, and thiocyanate. J Neurosci 16:6634-6647.

Patneau DK, Mayer ML (1991) Kinetic analysis of interactions between kainate and AMPA: evidence for activation of a single receptor in mouse hippocampal neurons. Neuron 6:785-798.

Patneau DK, Vyklicky L, Mayer ML (1993) Hippocampal neurons exhibit cyclothiazide-sensitive rapidly desensitizing responses to kainate. J Neurosci 13:3496-3509.

Raman IM, Zhang S, Trussell LO (1994) Pathway-specific variants of AMPA receptors and their contribution to neuronal signaling. J Neurosci 14:4998-5010.

Sato M, Kawashima Y, Goto J, Yamane Y, Chiba Y, Jinno S, Satake M, Iwata C (1994) Synthesis and evaluation of novel sulfonamide derivatives as thromboxane A2 receptor antagonists. Eur J Med Chem 29:185-190.

Sato M, Kawashima Y, Goto J, Yamane Y, Chiba Y, Jinno S, Satake M, Iwata C (1995) Synthesis and evaluation of novel fluorinated sulotroban-related sulfonamide derivatives as thromboxane A2 receptor antagonists. Eur J Med Chem 30:403-414.

Sekiguchi M, Doi K, Zhu WS, Watase K, Yokotani N, Wada K, Wenthold RJ (1994) A deletion in the second cytoplasmic loop of GluR3 produces a dominant negative mutant of alpha-amino-3hydroxy-5-methyl-4-isoxazole propionic acid receptor. J Biol Chem 269:14559-14565.

Sommer B, Keinänen K, Verdoorn TA, Wisden W, Burnashev N, Herb A, Köhler M, Takagi T, Sakmann B, Seeburg PH (1990) Flip and flop: a cell-specific functional switch in glutamate-operated channels of the CNS. Science 249:1580-1585.

Sommer B, Köhler M, Sprengel R, Seeburg PH (1991) RNA editing in brain controls a determinant of ion flow in glutamate-gated channels. Cell 67:11-19.

Staubli U, Perez Y, Xu FB, Rogers G, Ingvar M, Stone-Elander S, Lynch G (1994a) Centrally active modulators of glutamate receptors facilitate the induction of long-term potentiation in vivo. Proc Natl Acad Sci USA 91:11158-11162.

Staubli U, Rogers G, Lynch G (1994b) Facilitation of glutamate receptors enhances memory. Proc Natl Acad Sci USA 91:777-781.

Stein E, Cox JA, Seeburg PH, Verdoorn TA (1992) Complex pharmacological properties of recombinant alpha-amino-3-hydroxy-5-methyl4-isoxazole propionate receptor subtypes. Mol Pharmacol 42:864-871.

Stern-Bach Y, Bettler B, Hartley M, Sheppard PO, O'Hara PJ, Heinemann SF (1994) Agonist selectivity of glutamate receptors is specified by two domains structurally related to bacterial amino acid binding proteins. Neuron 13:1345-1357.

Sutcliffe M, Wo ZG, Oswald RE (1996) Three-dimensional models of non-NMDA glutamate receptors. Biophys J 70:1575-1589.

Swanson GT, Kamboj SK, Cull-Candy SG (1997) Single-channel properties of recombinant AMPA receptors depend on RNA editing, splice variation, and subunit composition. J Neurosci 17:58-69. 
Tang CM, Shi QY, Katchman A, Lynch G (1991) Modulation of the time course of fast EPSCs and glutamate channel kinetics by aniracetam. Science 254:288-290.

Trussell LO, Fischbach GD (1989) Glutamate receptor desensitization and its role in synaptic transmission. Neuron 3:209-218.

Trussell LO, Zhang S, Raman IM (1993) Desensitization of AMPA receptors upon multiquantal neurotransmitter release. Neuron 10:1185-1196.

Tsuzuki K, Takeuchi T, Ozawa S (1992) Agonist- and subunitdependent potentiation of glutamate receptors by a nootropic drug aniracetam. Mol Brain Res 16:105-110.

Verdoorn TA, Burnashev N, Monyer H, Seeburg PH, Sakmann B (1991) Structural determinants of ion flow through recombinant glutamate receptor channels. Science 252:1715-1718.

Vyklicky L, Patneau DK, Mayer ML (1991) Modulation of excitatory synaptic transmission by drugs that reduce desensitization at AMPA/ kainate receptors. Neuron 7:971-984.
Wenthold RJ, Yokotani N, Doi K, Wada K (1992) Immunochemical characterization of the non-NMDA glutamate receptor using subunitspecific antibodies. Evidence for a hetero-oligomeric structure in rat brain. J Biol Chem 267:501-507.

Yamada KA, Rothman SM (1992) Diazoxide reversibly blocks glutamate desensitization and prolongs excitatory postsynaptic currents in rat hippocampal neurons. J Physiol (Lond) 458:385-407.

Yamada KA, Tang CM (1993) Benzothiadiazines inhibit rapid glutamate receptor desensitization and enhance glutamatergic synaptic currents. J Neurosci 13:3904-3915.

Zivkovic D, Thompson DM, Bertolino M, DiBella M, Costa E, Guidotti A (1995) 7-Chloro-3-methyl-3-4-dihydro- ${ }^{2} \mathrm{H}-1,2,4$ benzothiadiazine $S, S$-dioxide (IDR A21): a benzothiadiazine derivative that enhances cognition by attenuating DL-amino-2,3-dihydro-5-methyl-3-oxo-4isoxazolepropanoic acid (AMPA) receptor desensitization. J Pharmacol Exp Ther 272:300-309. 